\title{
LEVEL II SCOUR ANALYSIS FOR BRIDGE 37 (DUXBTH00120037) on TOWN HIGHWAY 12, crossing RIDLEY BROOK, DUXBURY, VERMONT
}

U.S. Geological Survey Open-File Report 97-405

Prepared in cooperation with

VERMONT AGENCY OF TRANSPORTATION and

FEDERAL HIGHWAY ADMINISTRATION 


\section{LEVEL II SCOUR ANALYSIS FOR BRIDGE 37 (DUXBTH00120037) on TOWN HIGHWAY 12, crossing RIDLEY BROOK, DUXBURY, VERMONT \\ By EMILY C. WILD and MICHAEL A. IVANOFF}

U.S. Geological Survey Open-File Report 97-405

Prepared in cooperation with

VERMONT AGENCY OF TRANSPORTATION and

FEDERAL HIGHWAY ADMINISTRATION 


\title{
U.S. DEPARTMENT OF THE INTERIOR BRUCE BABBITT, Secretary
}

\author{
U.S. GEOLOGICAL SURVEY \\ Gordon P. Eaton, Director
}

For additional information write to:

District Chief

U.S. Geological Survey 361 Commerce Way

Pembroke, NH 03275-3718
Copies of this report may be purchased from:

U.S. Geological Survey

Branch of Information Services

Open-File Reports Unit

Box 25286

Denver, CO 80225-0286 


\section{CONTENTS}

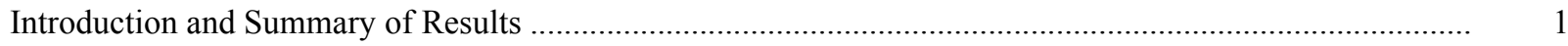

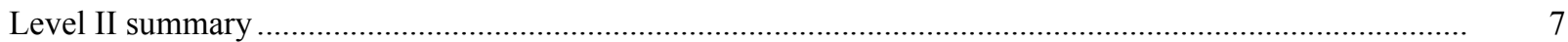

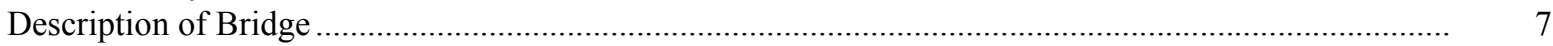

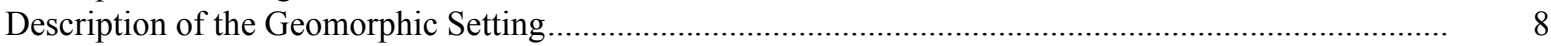

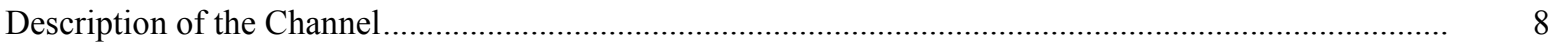

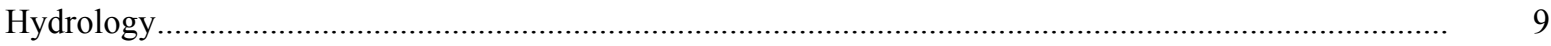

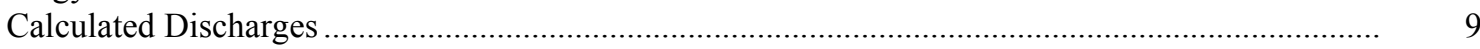

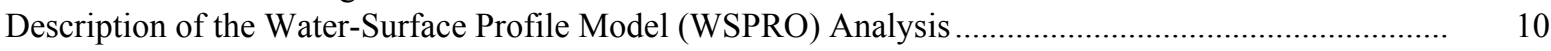

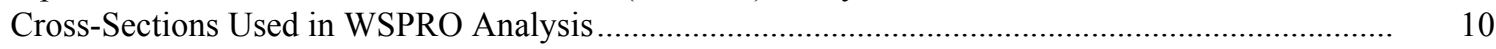

Data and Assumptions Used in WSPRO Model ..................................................................... 11

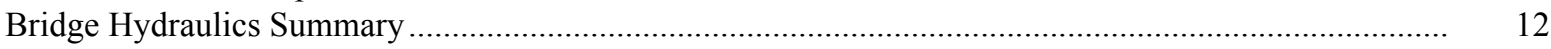

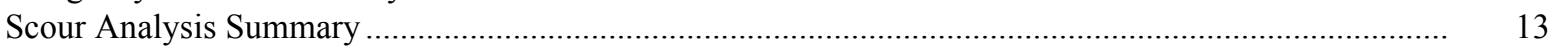

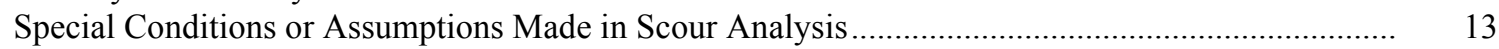

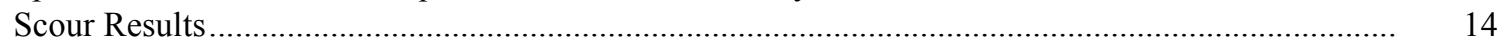

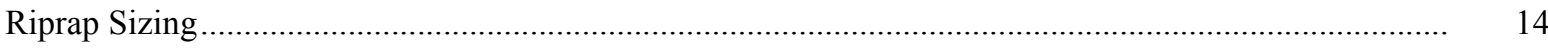

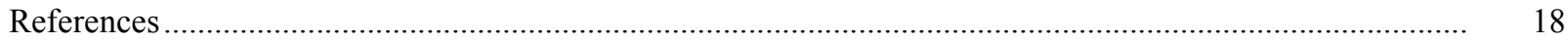

Appendixes:

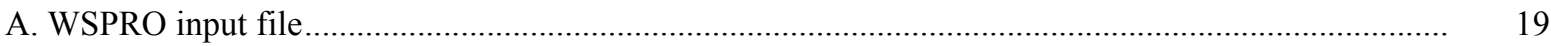

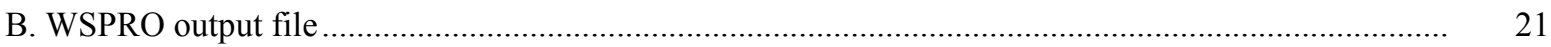

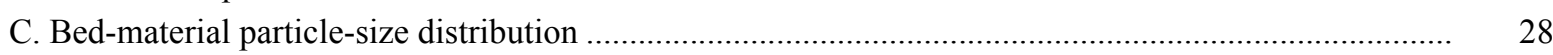

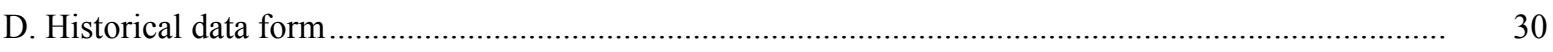

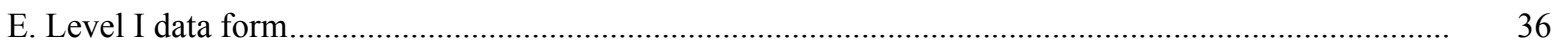

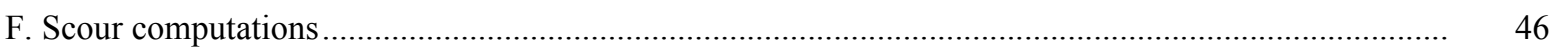

\section{FIGURES}

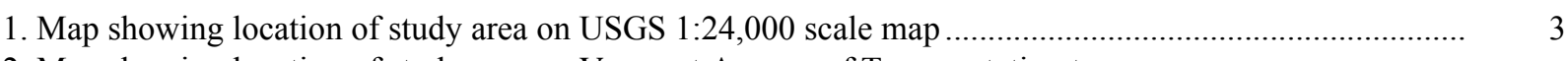

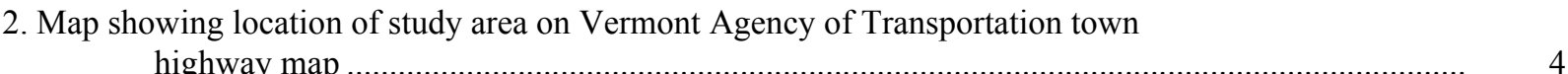

3. Structure DUXBTH00120037 viewed from upstream (July 1, 1996) ..................................................... 5

4. Downstream channel viewed from structure DUXBTH00120037 (July 1, 1996)................................ 5

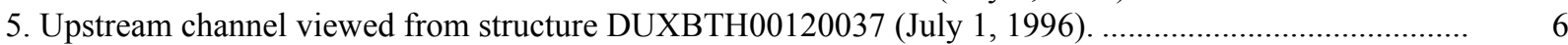

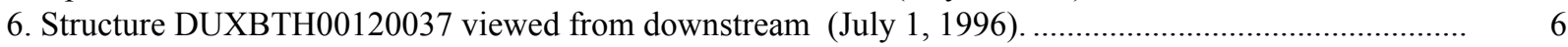

7. Water-surface profiles for the 100- and 500-year discharges at structure

DUXBTH00120037 on Town Highway 12, crossing Ridley Brook,

Duxbury, Vermont.....

8. Scour elevations for the 100- and 500-year discharges at structure

DUXBTH00120037 on Town Highway 12, crossing Ridley Brook,

Duxbury, Vermont.

3
5
5
6

(

\section{TABLES}

1. Remaining footing/pile depth at abutments for the 100-year discharge at structure

DUXBTH00120037 on Town Highway 12, crossing Ridley Brook,

Duxbury, Vermont ...

2. Remaining footing/pile depth at abutments for the 500-year discharge at structure

DUXBTH00120037 on Town Highway 12, crossing Ridley Brook,

Duxbury, Vermont 


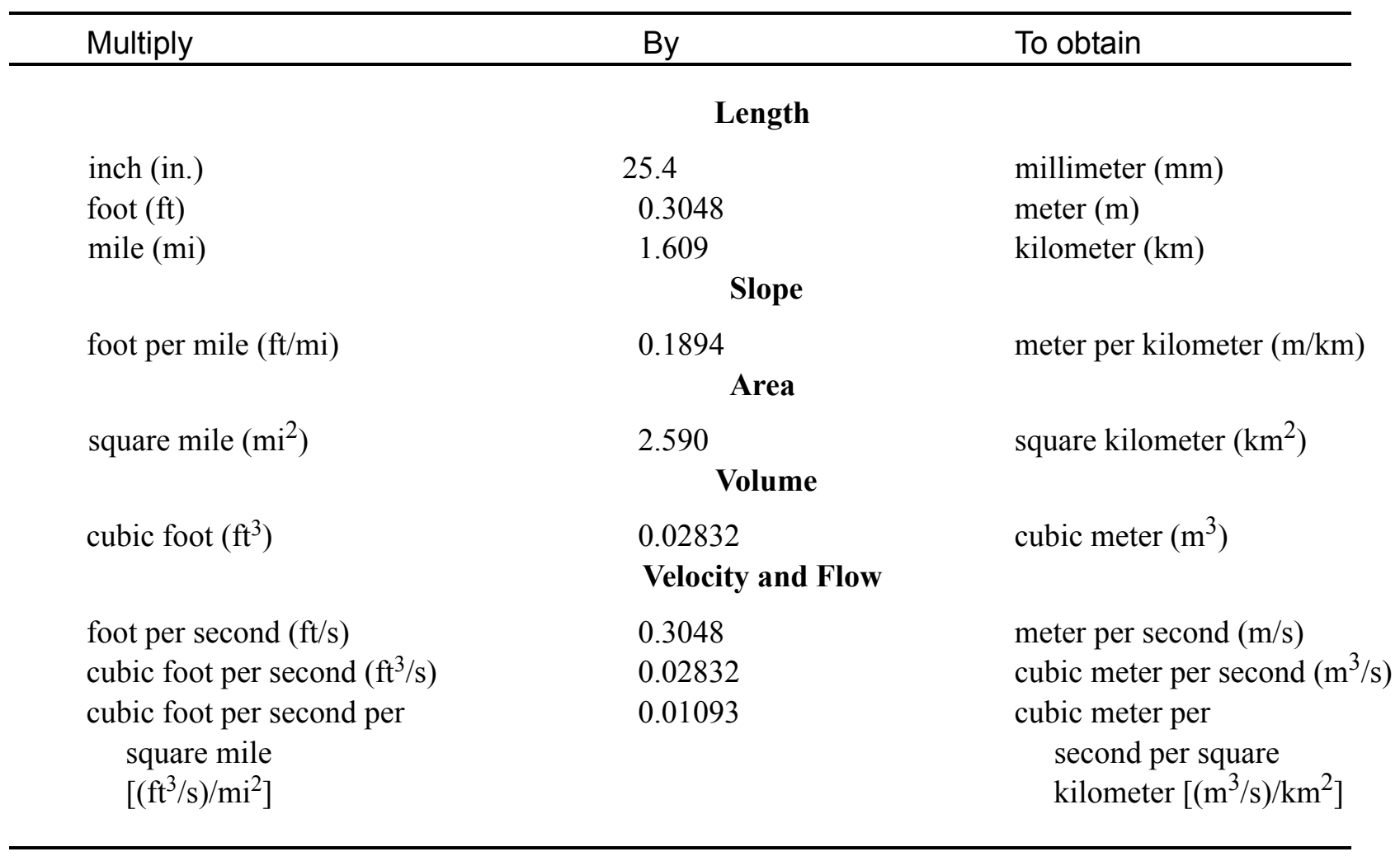

\section{OTHER ABBREVIATIONS}

$\begin{array}{lrlr}\mathrm{BF} & \text { bank full } & \text { LWW } & \text { left wingwall } \\ \mathrm{cfs} & \text { cubic feet per second } & \text { MC } & \text { main channel } \\ \mathrm{D}_{50} & \text { median diameter of bed material } & \text { RAB } & \text { right abutment } \\ \mathrm{DS} & \text { downstream } & \text { RABUT } & \text { face of right abutment } \\ \mathrm{elev} & \text { elevation } & \text { RB } & \text { right bank } \\ \mathrm{f} / \mathrm{p} & \text { flood plain } & \text { ROB } & \text { right overbank } \\ \mathrm{ft}^{2} & \text { square feet } & \text { RWW } & \text { right wingwall } \\ \mathrm{ft} / \mathrm{ft} & \text { feet per foot } & \text { TH } & \text { town highway } \\ \mathrm{JCT} & \text { junction } & \text { UB } & \text { under bridge } \\ \mathrm{LAB} & \text { left abutment } & \text { US } & \text { upstream } \\ \mathrm{LABUT} & \text { face of left abutment } & \text { USGS } & \text { United States Geological Survey } \\ \mathrm{LB} & \text { left bank } & \text { VTAOT Vermont Agency of Transportation } \\ \mathrm{LOB} & \text { left overbank } & \text { WSPRO } & \text { water-surface profile model }\end{array}$

In this report, the words "right" and "left" refer to directions that would be reported by an observer facing downstream. Sea level: In this report, "sea level" refers to the National Geodetic Vertical Datum of 1929-- a geodetic datum derived from a general adjustment of the first-order level nets of the United States and Canada, formerly called Sea Level Datum of 1929.

In the appendices, the above abbreviations may be combined. For example, USLB would represent upstream left bank. 


\title{
LEVEL II SCOUR ANALYSIS FOR BRIDGE 37 (DUXBTH00120037) ON TOWN HIGHWAY 12, CROSSING RIDLEY BROOK, DUXBURY, VERMONT
}

\author{
By Emily C. Wild and Michael A. Ivanoff
}

\section{INTRODUCTION AND SUMMARY OF RESULTS}

This report provides the results of a detailed Level II analysis of scour potential at structure DUXBTH00120037 on Town Highway 12 crossing Ridley Brook, Duxbury, Vermont (figures 1-8). A Level II study is a basic engineering analysis of the site, including a quantitative analysis of stream stability and scour (U.S. Department of Transportation, 1993). Results of a Level I scour investigation also are included in Appendix E of this report. A Level I investigation provides a qualitative geomorphic characterization of the study site. Information on the bridge, gleaned from Vermont Agency of Transportation (VTAOT) files, was compiled prior to conducting Level I and Level II analyses and is found in Appendix D.

The site is in the Green Mountain section of the New England physiographic province in north central Vermont. The $10.1-\mathrm{mi}^{2}$ drainage area is in a predominantly rural and forested basin. In the vicinity of the study site, the surface cover is forest upstream and downstream of the bridge.

In the study area, Ridley Brook has an incised, straight channel with a slope of approximately $0.04 \mathrm{ft} / \mathrm{ft}$, an average channel top width of $67 \mathrm{ft}$ and an average bank height of $9 \mathrm{ft}$. The channel bed material ranges from gravel to boulders with a median grain size $\left(\mathrm{D}_{50}\right)$ of $123 \mathrm{~mm}(0.404 \mathrm{ft})$. The geomorphic assessment at the time of the Level I and Level II site visit on July 1, 1996, indicated that the reach was stable.

The Town Highway 12 crossing of Ridley Brook is a 33-ft-long, two-lane bridge consisting of five 30-ft steel rolled beams (Vermont Agency of Transportation, written communication, October 13, 1995). The opening length of the structure parallel to the bridge face is $30 \mathrm{ft}$. The bridge is supported by vertical, concrete abutments with wingwalls. The channel is skewed approximately 50 degrees to the opening while the measured opening-skew-to-roadway is 20 degrees. 
A scour hole $2 \mathrm{ft}$ deeper than the mean thalweg depth was observed along the right abutment and downstream right wingwall during the Level I assessment. Scour countermeasures at the site include type-2 stone fill (less than 3 feet diameter) along the upstream and downstream left road embankments, and type-3 stone fill (less than 4 feet diameter) along the upstream right bank and upstream right wingwall. Additional details describing conditions at the site are included in the Level II Summary and Appendices D and E.

Scour depths and recommended rock rip-rap sizes were computed using the general guidelines described in Hydraulic Engineering Circular 18 (Richardson and others, 1995). Total scour at a highway crossing is comprised of three components: 1) long-term streambed degradation; 2) contraction scour (due to accelerated flow caused by a reduction in flow area at a bridge) and; 3 ) local scour (caused by accelerated flow around piers and abutments). Total scour is the sum of the three components. Equations are available to compute depths for contraction and local scour and a summary of the results of these computations follows.

Contraction scour for all modelled flows ranged from 0.6 to $1.7 \mathrm{ft}$. The worst-case contraction scour occurred at the 500-year discharge. Left abutment scour ranged from 5.0 to $8.3 \mathrm{ft}$, with the worst-case occurring at the incipient-overtopping discharge. Right abutment scour ranged from 13.1 to $16.7 \mathrm{ft}$, with the worst-case occurring at the 500-year discharge. Additional information on scour depths and depths to armoring are included in the section titled "Scour Results". Scoured-streambed elevations, based on the calculated scour depths, are presented in tables 1 and 2. A cross-section of the scour computed at the bridge is presented in figure 8 . Scour depths were calculated assuming an infinite depth of erosive material and a homogeneous particle-size distribution.

It is generally accepted that the Froehlich equation (abutment scour) gives "excessively conservative estimates of scour depths" (Richardson and others, 1995, p. 47). Usually, computed scour depths are evaluated in combination with other information including (but not limited to) historical performance during flood events, the geomorphic stability assessment, existing scour protection measures, and the results of the hydraulic analyses. Therefore, scour depths adopted by VTAOT may differ from the computed values documented herein. 


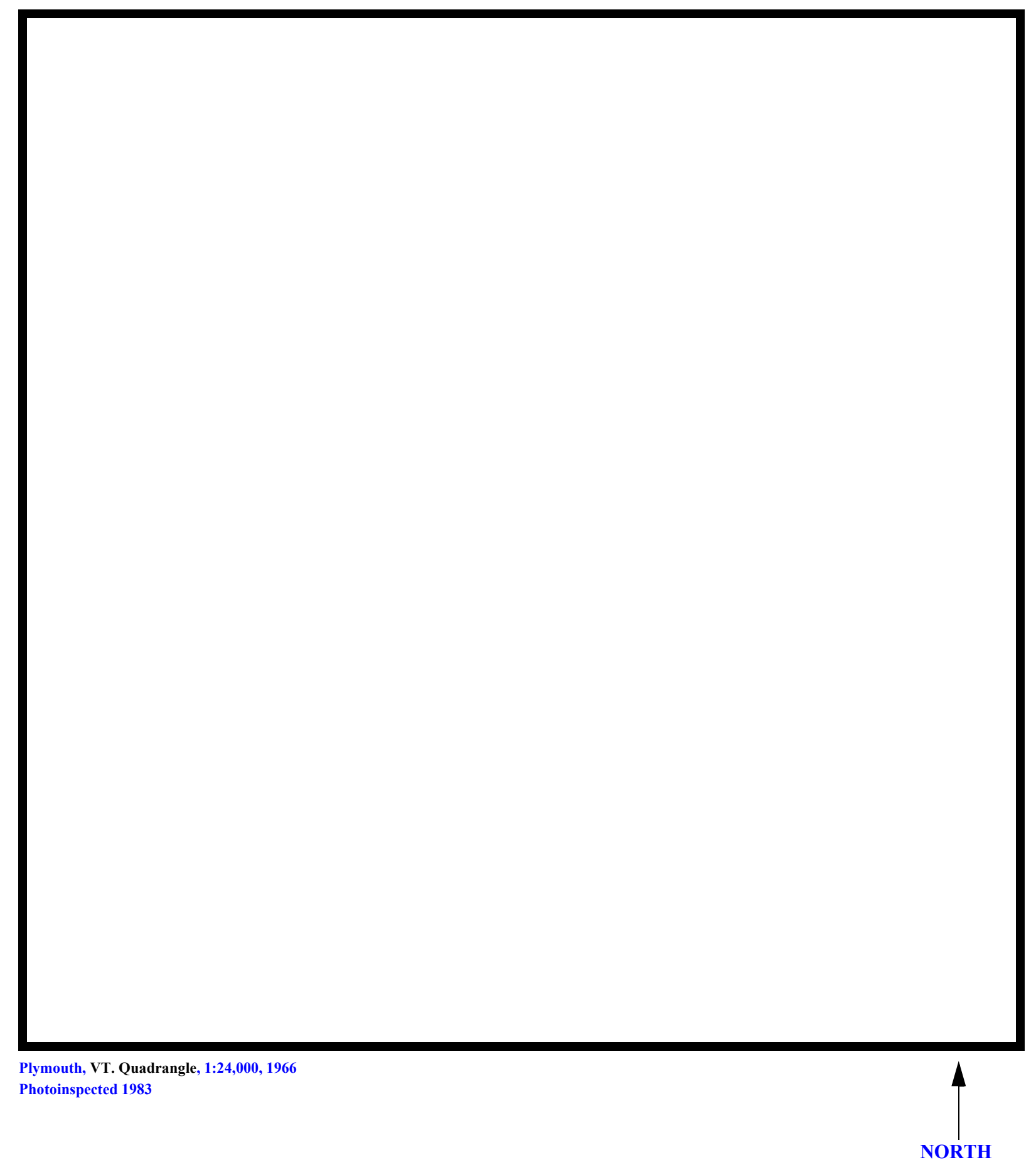

Figure 1. Location of study area on USGS 1:24,000 scale map. 
Figure 2. Location of study area on Vermont Agency of Transportation town highway map. 

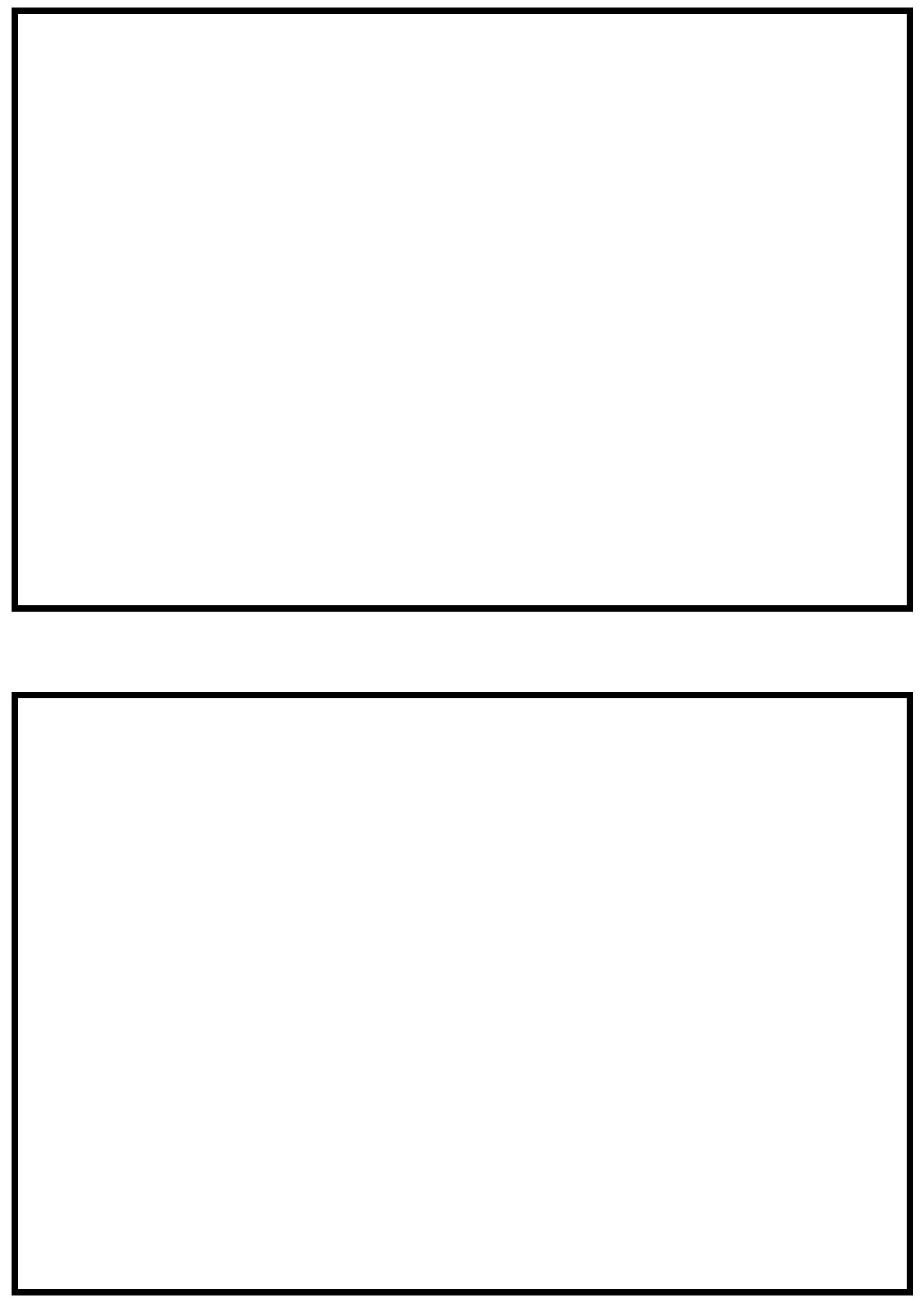

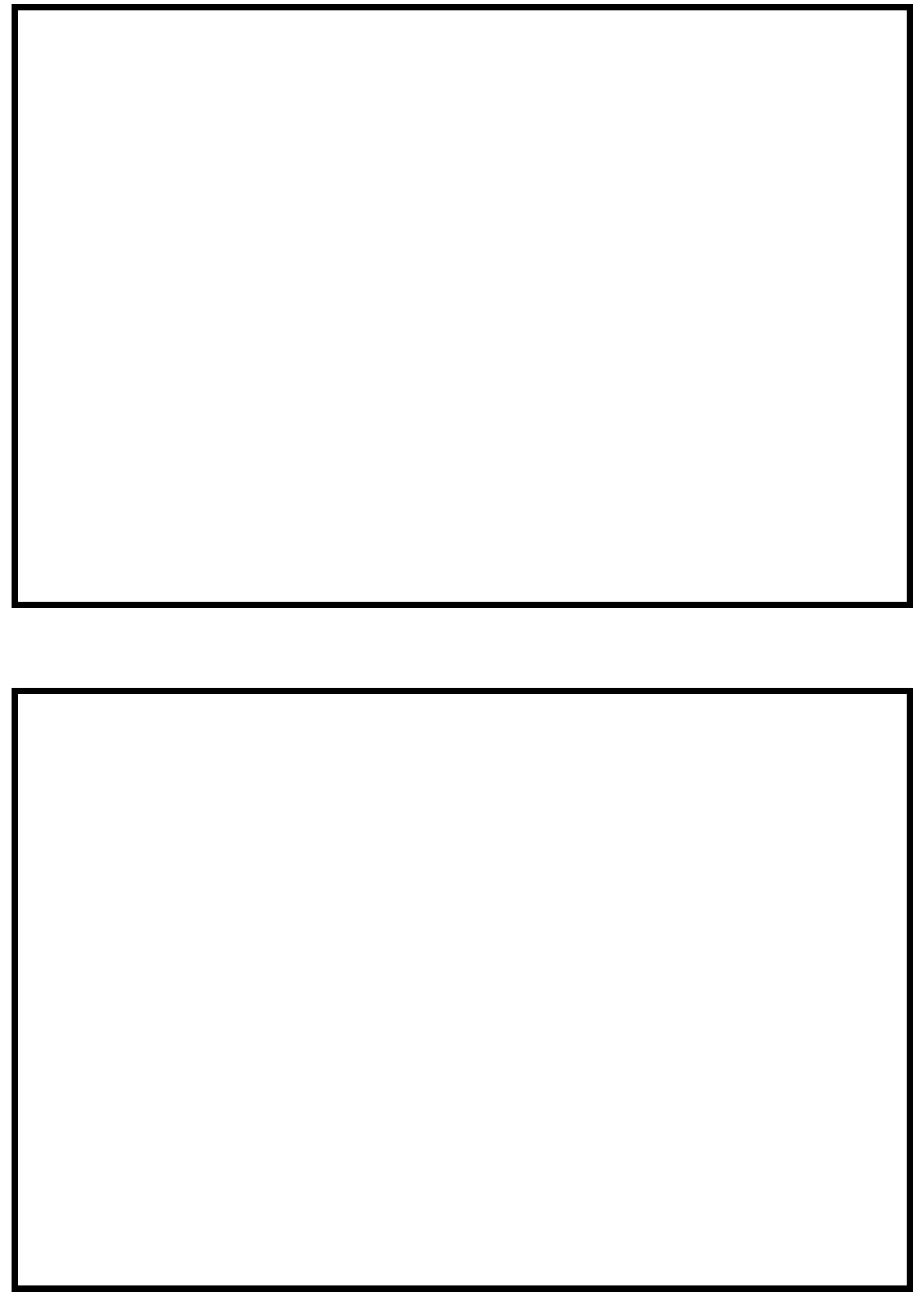


\section{LEVEL II SUMMARY}

\begin{tabular}{llllll} 
Structure Number & \multicolumn{2}{c}{ DUXBTH00120037 } & Stream & \multicolumn{3}{c}{ Ridley Brook } \\
& Road & TH12 & District & 6
\end{tabular}

\section{Description of Bridge}

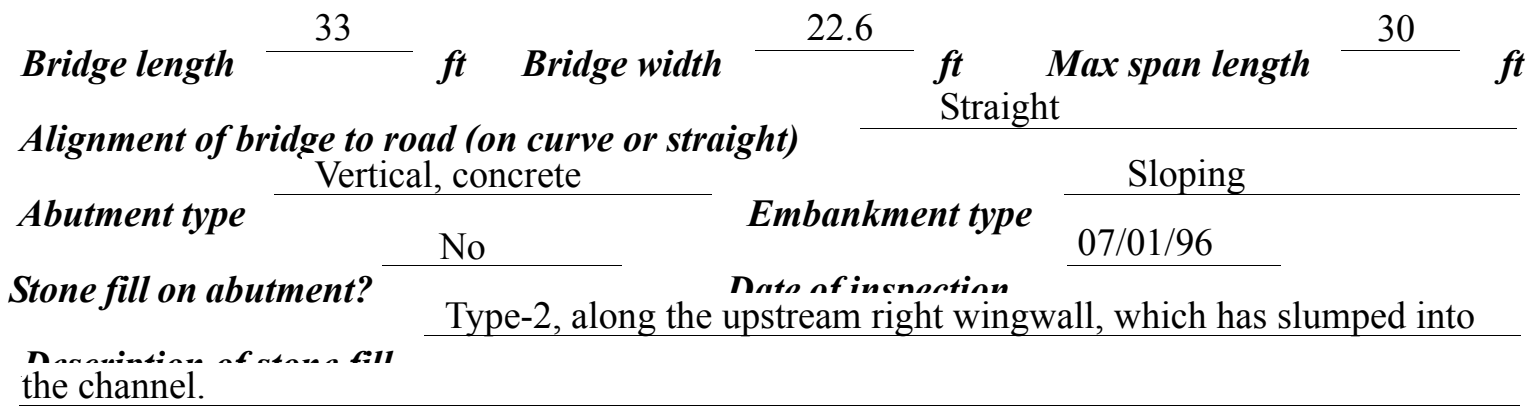

Abutments and wingwalls are concrete. There is a two foot deep scour hole along the downstream end of the right abutment and along the downstream right wingwall.

\section{$\mathrm{Y}$}

Is bridge skewed to flood flow according to Y Y survey?

Angle

There is a moderate channel bend in the upstream reach

Debris accumulation on bridge at time of Level I or Level II site visit:

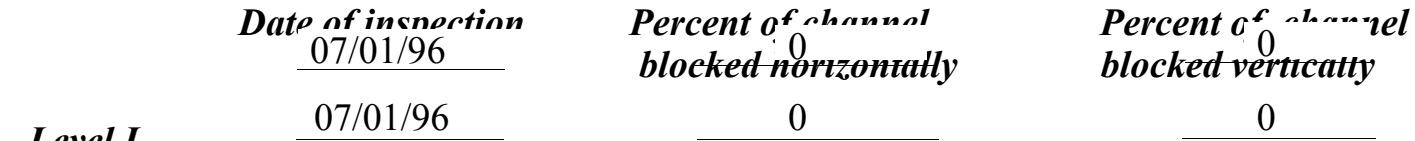

Level II

Moderate. There are some trees leaning into the channel upstream of the bridge.

Potential for debris

Doscriho anv, foaturos noar ar at the hridos that mav, affoct flou, (includo ahsorvation dato) None 0 7/01/96. 


\section{Description of the Geomorphic Setting}

General topography The channel is located within a steep valley.

$07 / 01 / 96$

Geomorphic conditions at bridge site: downstream (DS), upstream (US)

Date of inspection Moderately

DS left: $\quad$ sloping overbank.

DS right: $\quad$ Steep channel bank with a steep valley wall.

US left: $\quad$ Steep channel bank with a moderately sloping overbank.

US right: $\quad$ Steep valley wall.

\section{Description of the Channel}

\begin{tabular}{|c|c|c|c|}
\hline & & & 9 \\
\hline Average top width & $\stackrel{f t}{\text { B }}$ / Coulders / Cobbles & Average depth & Boulders/ Cobbles \\
\hline
\end{tabular}

Predominant bed material

Bank material

Straight and stable

with alluvial channel boundaries and a narrow flood plain.

$07 / 01 / 96$

Vegetative co 1 Forest

DS left: $\quad$ Forest

DS right: $\quad$ Trees with Town Highway 12 along immediate bank.

US left: $\quad$ Forest

US right: $\quad \underline{\mathrm{Y}}$

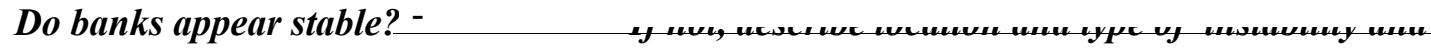

date of observatton.

None. 07/01/96

Describe any obstructions in channel and date of observation. 


\section{Hydrology}

Drainage area $\frac{10.1}{m_{i}{ }^{2}}$

Percentage of drainage area in physiographic provinces: (approximate)

Physiographic province/section

New England/Green Mountain
Percent of drainage area 100

Is drainage area considered rural or urban? Rural Describe any significant urbanization:

Is there a USGS gage on the stream of interest?

No

USGS gage description
USGS gage number
Gage drainage area

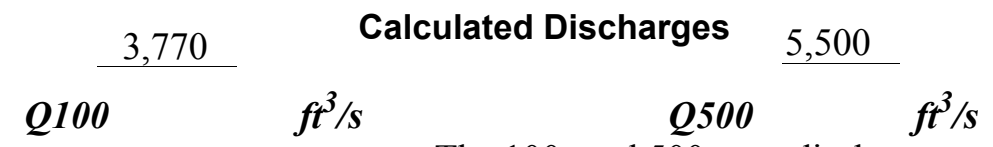

The 100- and 500-year discharges are based on a

drainage area relationship [(10,1/12.8)exp 0.7] with bridge number 6 in Duxbury. Bridge number 6 crosses the Ridley Brook downstream of this site and has flood frequency estimates available from the VTAOT database. The drainage area above bridge number 6 is 12.8 square miles. The values computed are within a range defined by several empirical flood frequency curves (Benson, 1962; Johnson and Tasker, 1974; FHWA, 1983; Potter, 1957a\&b; Talbot, 1887). 


\section{Description of the Water-Surface Profile Model (WSPRO) Analysis}

Datum for WSPRO analysis (USGS survey, sea level, VTAOT plans)

USGS survey

Datum tie between USGS survey and VTAOT plans

None

Description of reference marks used to determine USGS datum. $\quad$ RM1 is a chiseled X on top of the downstream end of the left abutment (elev. $498.97 \mathrm{ft}$, arbitrary survey datum). RM2 is a chiseled X on top of the upstream end of the right abutment (elev. $498.78 \mathrm{ft}$, arbitrary survey datum).

\section{Cross-Sections Used in WSPRO Analysis}

\begin{tabular}{cccl}
\hline${ }^{1}$ Cross-section & $\begin{array}{c}\text { Section } \\
\text { Reference } \\
\text { Distance } \\
\text { (SRD) in feet }\end{array}$ & $\begin{array}{c}{ }^{2} \text { Cross-section } \\
\text { development }\end{array}$ & \multicolumn{1}{c}{ Comments } \\
\hline EXITX & -39 & 1 & Exit section \\
FULLV & 0 & 2 & $\begin{array}{l}\text { Downstream Full-valley } \\
\text { section (Templated from } \\
\text { EXITX) }\end{array}$ \\
BRIDG & 0 & 1 & Bridge section \\
RDWAY & 11 & 1 & Road Grade section \\
APPRO & 55 & 1 & Approach section \\
\hline
\end{tabular}

${ }^{1}$ For location of cross-sections see plan-view sketch included with Level I field form, Appendix E. For more detail on how cross-sections were developed see WSPRO input file. 


\section{Data and Assumptions Used in WSPRO Model}

Hydraulic analyses of the reach were done by use of the Federal Highway Administration's WSPRO step-backwater computer program (Shearman and others, 1986, and Shearman, 1990). The analyses reported herein reflect conditions existing at the site at the time of the study. Furthermore, in the development of the model it was necessary to assume no accumulation of debris or ice at the site. Results of the hydraulic model are presented in the Bridge Hydraulic Summary, Appendix B, and figure 7.

Channel roughness factors (Manning's “n”) used in the hydraulic model were estimated using field inspections at each cross section following the general guidelines described by Arcement and Schneider (1989). Final adjustments to the values were made during the modelling of the reach. Channel " $n$ " values for the reach ranged from 0.040 to 0.070 , and overbank " $n$ " values ranged from 0.065 to 0.070 .

Normal depth at the exit section (EXITX) was assumed as the starting water surface. This depth was computed by use of the slope-conveyance method outlined in the user's manual for WSPRO (Shearman, 1990). The slope used was $0.0426 \mathrm{ft} / \mathrm{ft}$ which was estimated from thalweg slopes surveyed downstream.

The approach section (APPRO) was modelled one bridge length upstream of the upstream face as recommended by Shearman and others (1986). This location also provides a consistent method for determining scour variables.

For the incipient roadway-overtopping discharge, WSPRO assumes critical depth at the bridge section. Supercritical models were developed for these discharges. After analyzing both the supercritical and subcritical profiles for each discharge, it can be determined that the water surface profile does pass through critical depth within the bridge opening. Thus, the assumptions of critical depth at the bridge are satisfactory solutions. 


\section{Bridge Hydraulics Summary}

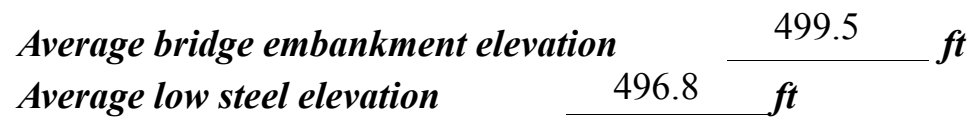

$$
\text { 100-year discharge } \quad 3,770 \quad \mathrm{ft}^{3} / \mathrm{s}
$$

Water-surface elevation in bridge opening $\quad 497.0 \quad f t$

Road overtopping? ___ Y Discharge over road __ $767 \quad \mathrm{ft}^{3} / \mathrm{s}$

Area of flow in bridge opening $\quad 226 \quad \mathrm{ft}^{2}$

Average velocity in bridge opening $13.3 \mathrm{ft} / \mathrm{s}$

Maximum WSPRO tube velocity at bridge $\quad 15.5 \mathrm{ft} / \mathrm{s}$

Water-surface elevation at Approach section with bridge $\quad 500.8$

Water-surface elevation at Approach section without bridge $\quad 498.5$

Amount of backwater caused by bridge

$2.3 \quad i$

500-year discharge $\quad 5,500 \quad \mathrm{ft}^{3} / \mathrm{s}$

Water-surface elevation in bridge opening $\quad 497.0 \mathrm{ft}$

Road overtopping? ___ Y Discharge over road __ 2,393 $\mathrm{ft}^{3} / \mathrm{s}$

Area of flow in bridge opening $\quad 226 \quad \mathrm{ft}^{2}$

Average velocity in bridge opening $\quad 13.8 \mathrm{ft} / \mathrm{s}$

Maximum WSPRO tube velocity at bridge 16.0 's

Water-surface elevation at Approach section with bridge 502.8

Water-surface elevation at Approach section without bridge $\quad 500.0$

Amount of backwater caused by bridge $\quad 2.8$ t

Incipient overtopping discharge $\quad 2,320 \mathrm{ft}^{3} / \mathrm{s}$

Water-surface elevation in bridge opening $\quad 494.7 \quad$ t

Area of flow in bridge opening $\quad \begin{array}{lll}168 & \mathrm{ft}^{2}\end{array}$

Average velocity in bridge opening $\quad 13.8 \quad \mathrm{ft} / \mathrm{s}$

Maximum WSPRO tube velocity at bridge $\quad 16.9 \mathrm{ft} / \mathrm{s}$

Water-surface elevation at Approach section with bridge

Water-surface elevation at Approach section without bridge

497.7

Amount of backwater caused by bridge $\quad \begin{array}{ll}0.9 & \text { it }\end{array}$ 


\section{Scour Analysis Summary}

\section{Special Conditions or Assumptions Made in Scour Analysis}

Scour depths were computed using the general guidelines described in Hydraulic Engineering Circular 18 (Richardson and others, 1995). Scour depths were calculated assuming an infinite depth of erosive material and a homogeneous particle-size distribution. The results of the scour analysis are presented in tables 1 and 2 and a graph of the scour depths is presented in figure 8 .

Contraction scour for the incipient roadway-overtopping discharge was computed by use of Laursen's clear-water contraction scour equation (Richardson and others, 1995, p. 32, equation 20). At this site, the 100-year and 500-year discharges resulted in submerged orifice flow. Contraction scour at bridges with orifice flow is best estimated by use of the Chang pressure-flow scour equation (oral communication, J. Sterling Jones, October 4, 1996). Thus, contraction scour for these discharges was computed by use of the Chang equation (Richardson and others, 1995, p. 145-146). Results of this analysis are presented in figure 8 and tables 1 and 2 . The streambed armoring depths computed suggest that armoring will not limit the depth of contraction scour.

Additional estimates of contraction scour for the 100-year and 500-year discharges also were computed by use of Laursen's clear-water scour equation (Richardson and others, 1995, p. 32, equation 20) and Umbrell's pressure-flow scour equation (Richardson and other, 1995, p. 144-146), and the results are presented in Appendix F.

Abutment scour for the left and right abutments was computed by use of the Froehlich equation (Richardson and others, 1995, p. 48, equation 28). Variables for the Froehlich equation include the Froude number of the flow approaching the embankments, the length of the embankment blocking flow, and the depth of flow approaching the embankment less any roadway overtopping. 


\section{Scour Results}

100-yr discharge 500-yr discharge

Contraction scour:

(Scour depths in feet)

Main channel

Live-bed scour

Clear-water scour

Depth to armoring

Left overbank

Right overbank

Local scour:

Abutment scour

5.06 .2

8.316 .1

16.7

Left abutment

$13.1-$

Right abutment

Pier scour

Pier 1

Pier 2
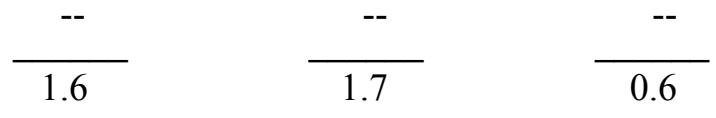

$15.9^{-}$

$18.7^{-}$

$28.3^{-}$

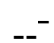

---

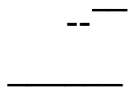

$---$

$--$

overtopping discharge

Pier 3

\section{Riprap Sizing}

\section{Abutments:}

Left abutment

\section{Right abutment}

Piers:

Pier 1

Pier 2

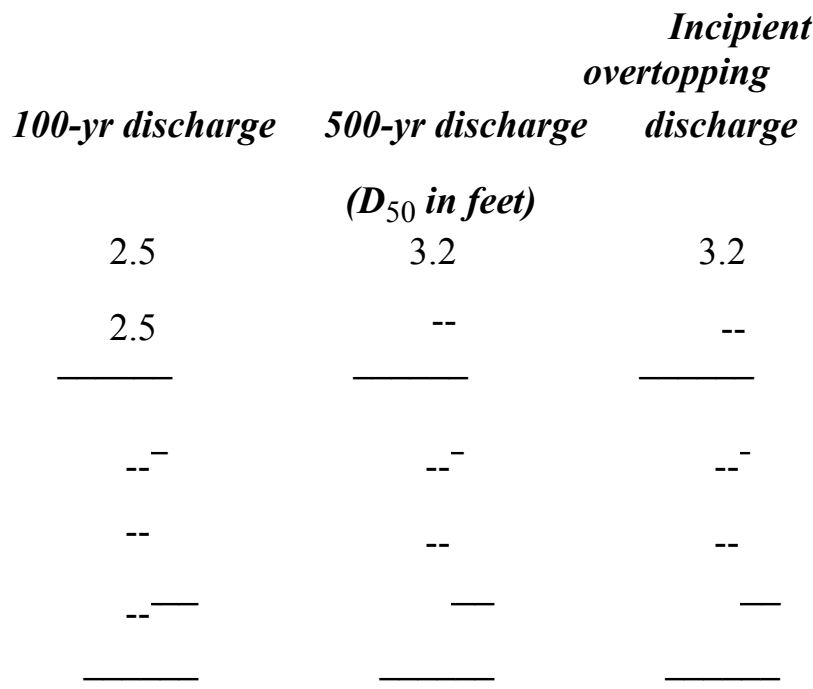




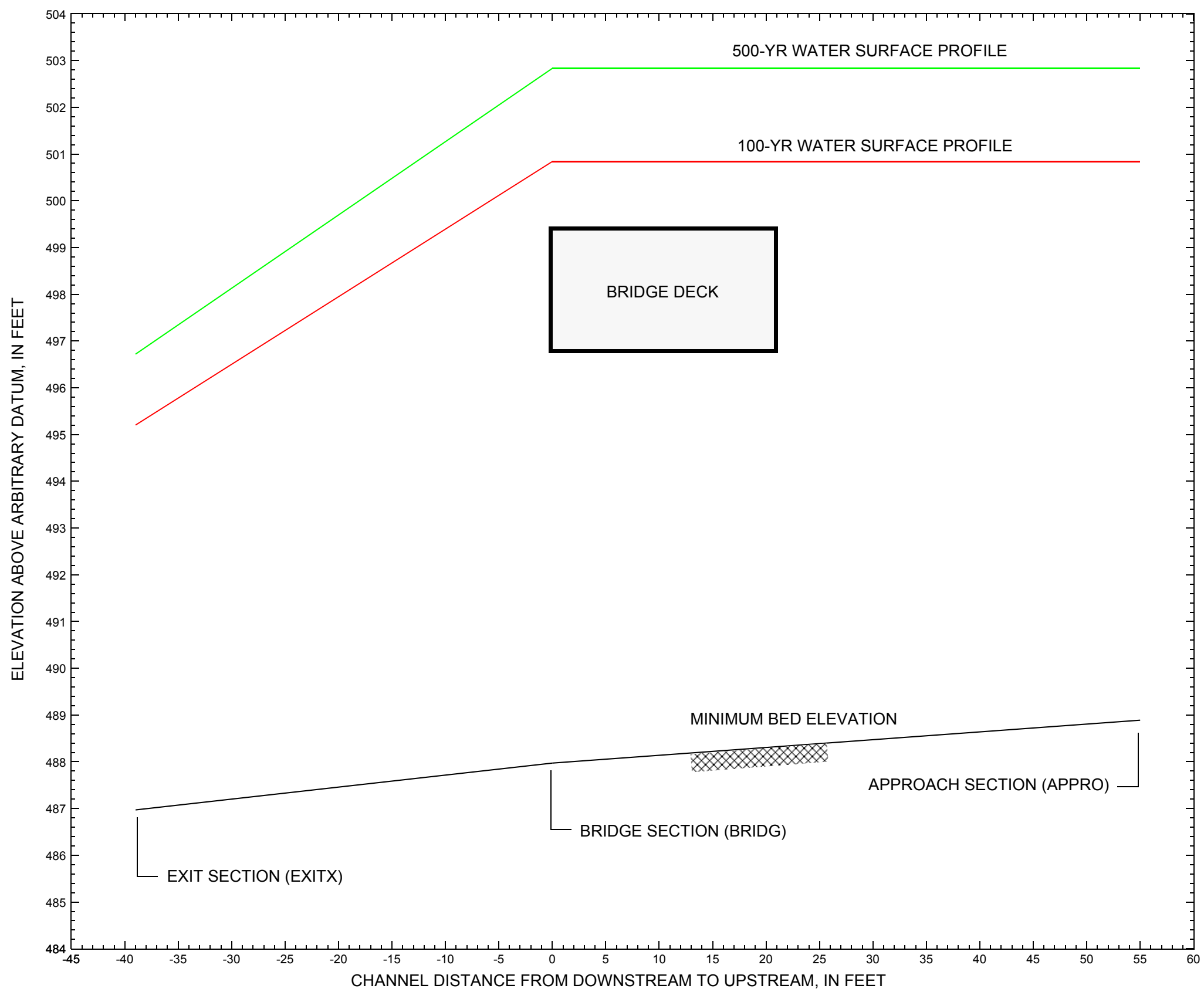

Figure 7. Water-surface profiles for the 100- and 500-yr discharges at structure DUXBTH00120037 on Town Highway 12, crossing Ridley Brook, Duxbury, Vermont. 


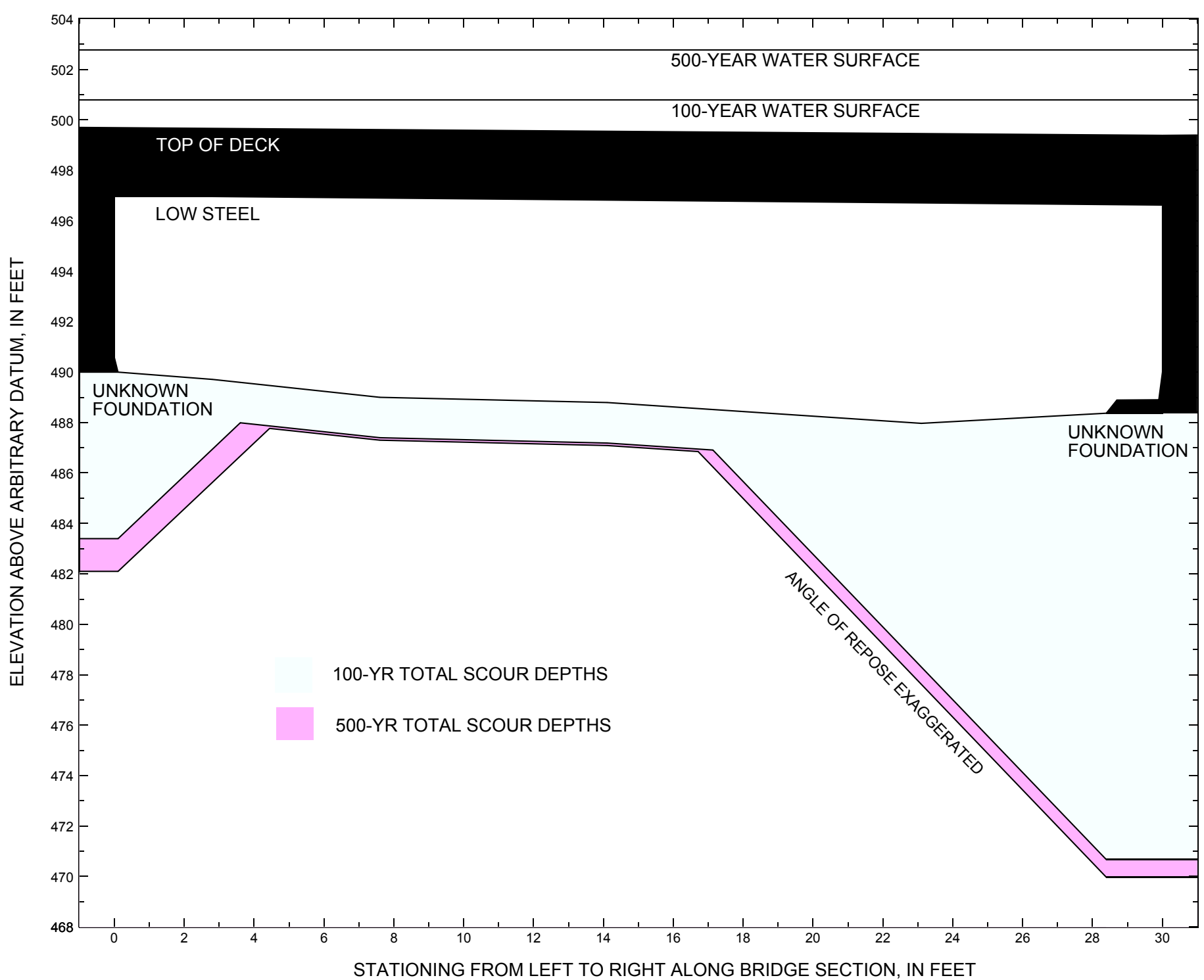

Figure 8. Scour elevations for the 100-yr and 500-yr discharges at structure DUXBTH00120037 on Town Highway 12, crossing Ridley Brook, Duxbury, Vermont. 
Table 1. Remaining footing/pile depth at abutments for the 100-year discharge at structure DUXBTH00120037 on Town Highway 12, crossing Ridley Brook, Duxbury, Vermont.

[VTAOT, Vermont Agency of Transportation; --,no data]

\begin{tabular}{|c|c|c|c|c|c|c|c|c|c|c|c|}
\hline Description & Station $^{1}$ & $\begin{array}{l}\text { VTAOT } \\
\text { minimum } \\
\text { low-chord } \\
\text { elevation } \\
\text { (feet) }\end{array}$ & $\begin{array}{l}\text { Surveyed } \\
\text { minimum } \\
\text { low-chord } \\
\text { elevation } \\
\text { (feet) }\end{array}$ & $\begin{array}{c}\text { Bottom of } \\
\text { footing } \\
\text { elevation } \\
\text { (feet) }\end{array}$ & $\begin{array}{l}\text { Channel } \\
\text { elevation at } \\
\text { abutment/ } \\
\text { pier }^{2} \\
\text { (feet) }\end{array}$ & $\begin{array}{l}\text { Contraction } \\
\text { scour depth } \\
\text { (feet) }\end{array}$ & $\begin{array}{l}\text { Abutment } \\
\text { scour } \\
\text { depth } \\
\text { (feet) }\end{array}$ & $\begin{array}{l}\text { Pier } \\
\text { scour } \\
\text { depth } \\
\text { (feet) }\end{array}$ & $\begin{array}{l}\text { Depth of } \\
\text { total scour } \\
\text { (feet) }\end{array}$ & $\begin{array}{c}\text { Elevation of } \\
\text { scour }^{2} \\
\text { (feet) }\end{array}$ & $\begin{array}{c}\text { Remaining } \\
\text { footing/pile } \\
\text { depth } \\
\text { (feet) }\end{array}$ \\
\hline \multicolumn{12}{|c|}{100 -yr. discharge is 3,770 cubic-feet per second } \\
\hline Left abutment & 0.0 & -- & 497.0 & -- & 490.0 & 1.6 & 5.0 & -- & 6.6 & 483.4 & -- \\
\hline Right abutment & 30.0 & -- & 496.6 & -- & 488.4 & 1.6 & 16.1 & -- & 17.7 & 470.7 & -- \\
\hline
\end{tabular}

1.Measured along the face of the most constricting side of the bridge.

2.Arbitrary datum for this study.

Table 2. Remaining footing/pile depth at abutments for the 500-year discharge at structure DUXBTH00120037 on Town Highway 12, crossing Ridley Brook, Duxbury, Vermont.

[VTAOT, Vermont Agency of Transportation; --, no data]

\begin{tabular}{|c|c|c|c|c|c|c|c|c|c|c|c|}
\hline Description & Station $^{1}$ & $\begin{array}{l}\text { VTAOT } \\
\text { minimum } \\
\text { low-chord } \\
\text { elevation } \\
\text { (feet) }\end{array}$ & $\begin{array}{c}\text { Surveyed } \\
\text { minimum } \\
\text { low-chord } \\
\text { elevation } \\
\text { (feet) }\end{array}$ & $\begin{array}{c}\text { Bottom of } \\
\text { footing } \\
\text { elevation } \\
\text { (feet) }\end{array}$ & $\begin{array}{c}\text { Channel } \\
\text { elevation at } \\
\text { abutment/ } \\
\text { pier }^{2} \\
\text { (feet) }\end{array}$ & $\begin{array}{l}\text { Contraction } \\
\text { scour depth } \\
\text { (feet) }\end{array}$ & $\begin{array}{l}\text { Abutment } \\
\text { scour } \\
\text { depth } \\
\text { (feet) }\end{array}$ & $\begin{array}{l}\text { Pier } \\
\text { scour } \\
\text { depth } \\
\text { (feet) }\end{array}$ & $\begin{array}{l}\text { Depth of } \\
\text { total scour } \\
\text { (feet) }\end{array}$ & $\begin{array}{c}\text { Elevation of } \\
\text { scour }^{2} \\
\text { (feet) }\end{array}$ & $\begin{array}{c}\text { Remaining } \\
\text { footing/pile } \\
\text { depth } \\
\text { (feet) }\end{array}$ \\
\hline \multicolumn{12}{|c|}{500 -yr. discharge is 5,500 cubic-feet per second } \\
\hline Left abutment & 0.0 & -- & 497.0 & -- & 490.0 & 1.7 & 6.2 & -- & 7.9 & 482.1 & -- \\
\hline Right abutment & 30.0 & -- & 496.6 & -- & 488.4 & 1.7 & 16.7 & -- & 18.4 & 470.0 & -- \\
\hline
\end{tabular}

1.Measured along the face of the most constricting side of the bridge.

2.Arbitrary datum for this study. 


\section{SELECTED REFERENCES}

Arcement, G.J., Jr., and Schneider, V.R., 1989, Guide for selecting Manning's roughness coefficients for natural channels and flood plains:

U.S. Geological Survey Water-Supply Paper 2339, 38 p.

Barnes, H.H., Jr., 1967, Roughness characteristics of natural channels: U.S. Geological Survey Water-Supply Paper 1849,213 p.

Benson, M. A., 1962, Factors Influencing the Occurrence of Floods in a Humid Region of Diverse Terrain: U.S. Geological Survey WaterSupply Paper 1580-B, 64 p.

Brown, S.A. and Clyde, E.S., 1989, Design of riprap revetment: Federal Highway Administration Hydraulic Engineering Circular No. 11, Publication FHWA-IP-89-016, 156 p.

Federal Highway Administration, 1983, Runoff estimates for small watersheds and development of sound design: Federal Highway Administration Report FHWA-RD-77-158.

Federal Highway Administration, 1993, Stream Stability and Scour at Highway Bridges: Participant Workbook: Federal Highway Administration Report FHWA-HI-91-011.

Federal Emergency Management Agency, 1981, Flood Insurance Study, Town of Duxbury, Washington County, Vermont: Washington, D.C., September 15, 1981.

Froehlich, D.C., 1989, Local scour at bridge abutments in Ports, M.A., ed., Hydraulic Engineering--Proceedings of the 1989 National Conference on Hydraulic Engineering: New York, American Society of Civil Engineers, p. 13-18.

Hayes, D.C.,1993, Site selection and collection of bridge-scour data in Delaware, Maryland, and Virginia: U.S. Geological Survey WaterResources Investigation Report 93-4017, 23 p.

Interagency Advisory Committee on Water Data, 1982, Guidelines for determining flood flow frequency: U.S. Geological Survey, Bulletin 17B of the Hydrology Subcommittee, 190 p.

Johnson, C.G. and Tasker, G.D.,1974, Progress report on flood magnitude and frequency of Vermont streams: U.S. Geological Survey OpenFile Report 74-130, 37 p.

Lagasse, P.F., Schall, J.D., Johnson, F., Richardson, E.V., Chang, F., 1995, Stream Stability at Highway Structures: Federal Highway Administration Hydraulic Engineering Circular No. 20, Publication FHWA-IP-90-014, 144 p.

Laursen, E.M., 1960, Scour at bridge crossings: Journal of the Hydraulics Division, American Society of Civil Engineers, v. 86, no. HY2, p. 39-53.

Potter, W. D., 1957a, Peak rates of runoff in the Adirondack, White Mountains, and Maine woods area, Bureau of Public Roads

Potter, W. D., 1957b, Peak rates of runoff in the New England Hill and Lowland area, Bureau of Public Roads

Richardson, E.V. and Davis, S.R., 1995, Evaluating scour at bridges: Federal Highway Administration Hydraulic Engineering Circular No. 18, Publication FHWA-IP-90-017, 204 p.

Richardson, E.V., Simons, D.B., and Julien, P.Y., 1990, Highways in the river environment: Federal Highway Administration Publication FHWA-HI-90-016.

Ritter, D.F., 1984, Process Geomorphology: W.C. Brown Co., Debuque, Iowa, 603 p.

Shearman, J.O., 1990, User's manual for WSPRO--a computer model for water surface profile computations: Federal Highway Administration Publication FHWA-IP-89-027, 187 p.

Shearman, J.O., Kirby, W.H., Schneider, V.R., and Flippo, H.N., 1986, Bridge waterways analysis model; research report: Federal Highway Administration Publication FHWA-RD-86-108, 112 p.

Talbot, A.N., 1887, The determination of water-way for bridges and culverts.

U.S. Department of Transportation, 1993, Stream stability and scour at highway bridges, Participant Workbook: Federal Highway Administration Publication FHWA HI-91-011.

U.S. Geological Survey, 1948, Waterbury, Vermont 7.5 Minute Series quadrangle map: U.S. Geological Survey Topographic Maps, Photoinspected 1980, Scale 1:24,000. 


\section{APPENDIX A: \\ WSPRO INPUT FILE}




\section{WSPRO INPUT FILE}

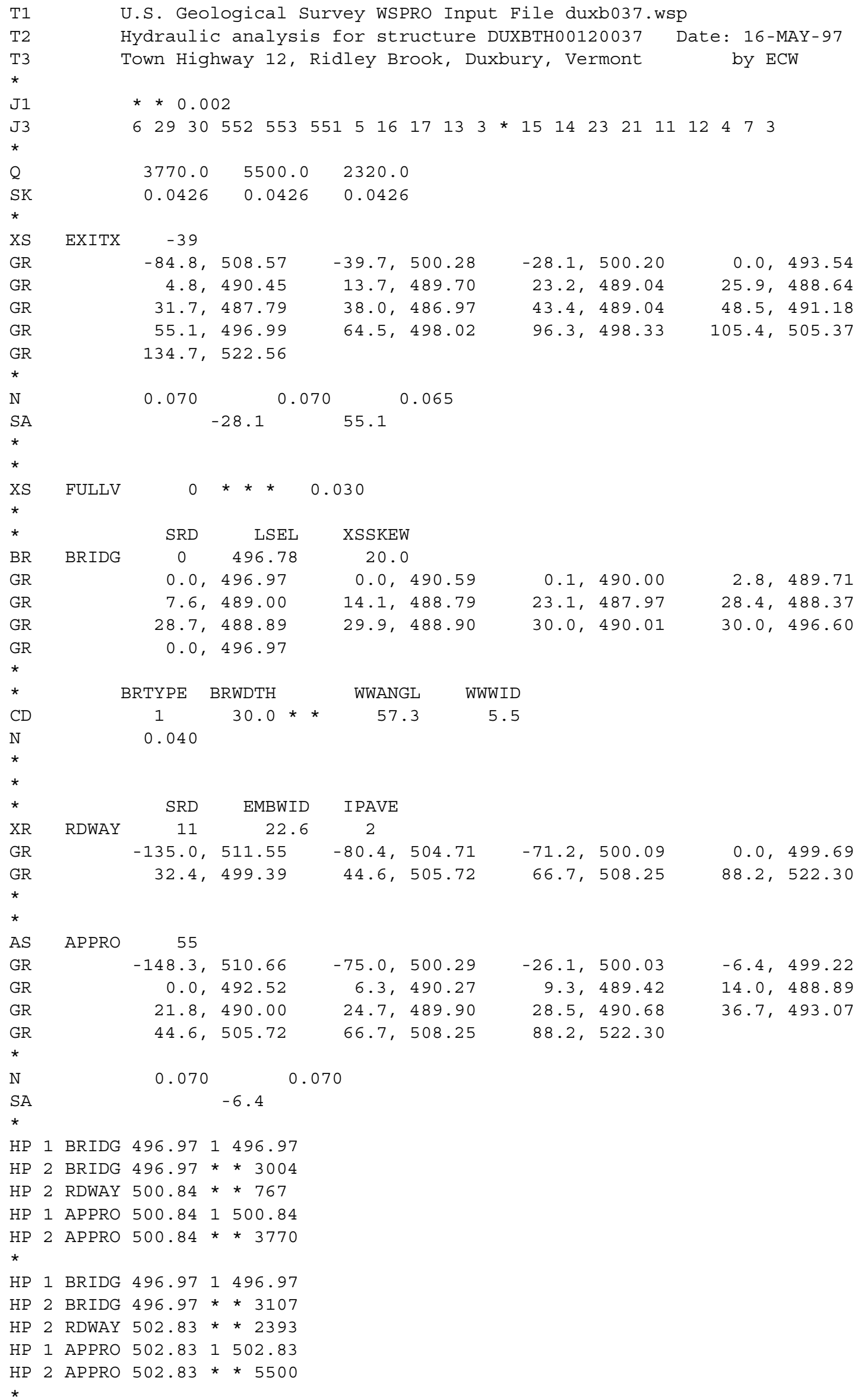




\section{APPENDIX B: \\ WSPRO OUTPUT FILE}


WSPRO OUTPUT FILE

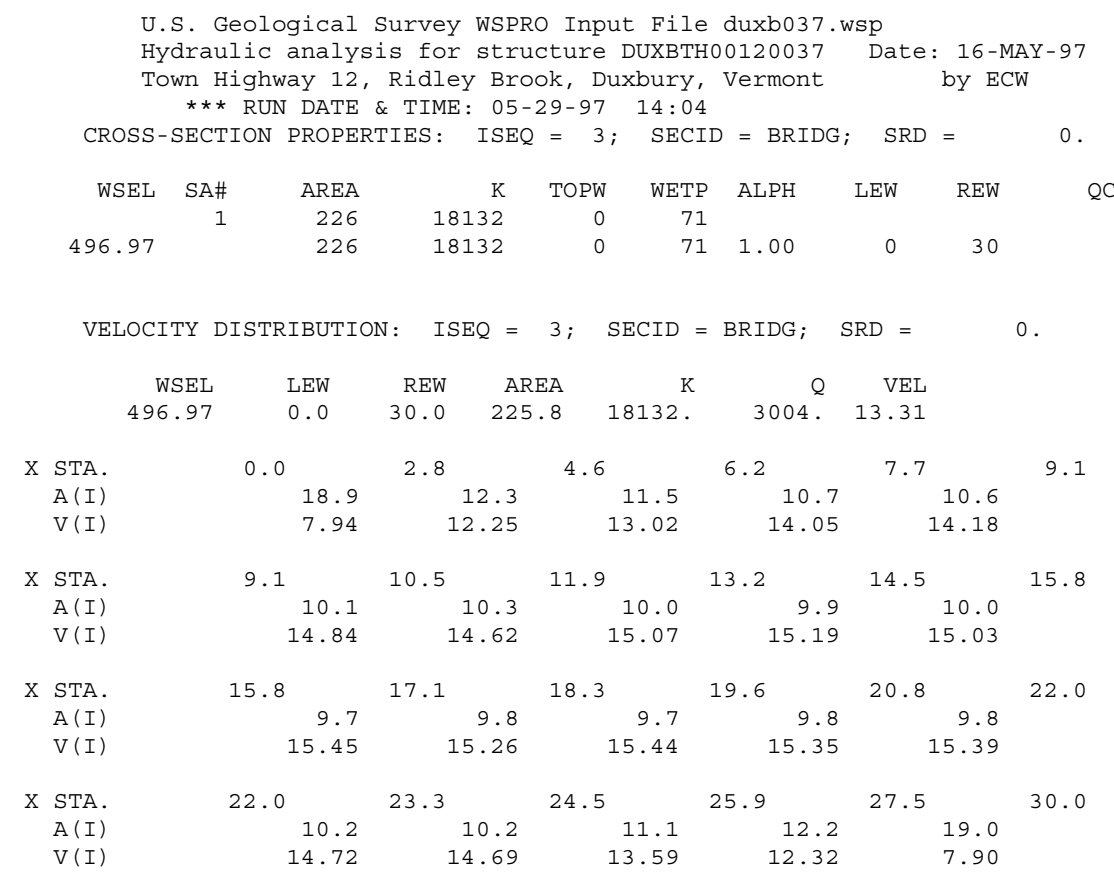

VELOCITY DISTRIBUTION : ISEQ $=4 ; \operatorname{SECID~=~RDWAY~} ; \quad \operatorname{SRD}=$

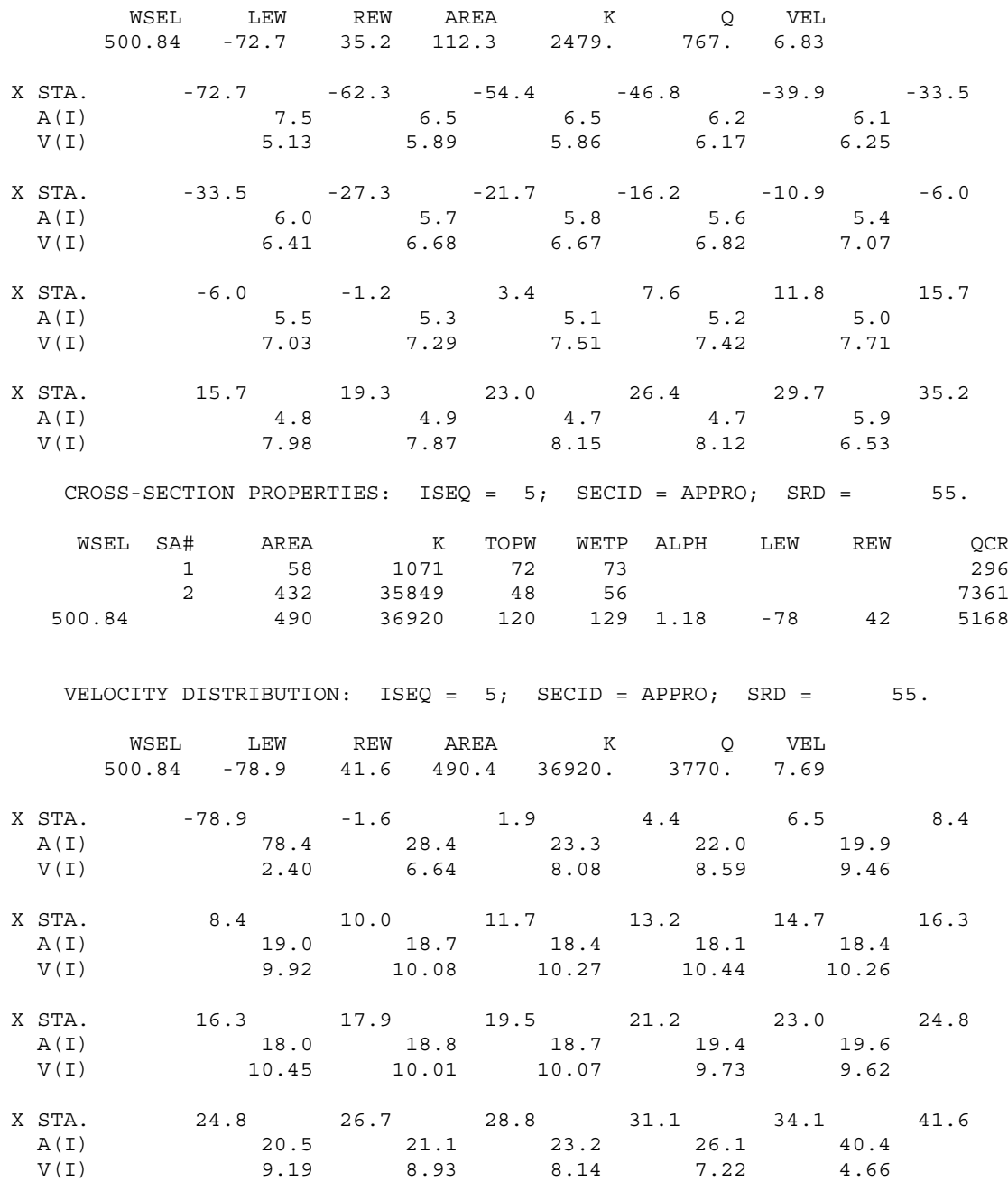


WSPRO OUTPUT FILE (continued)

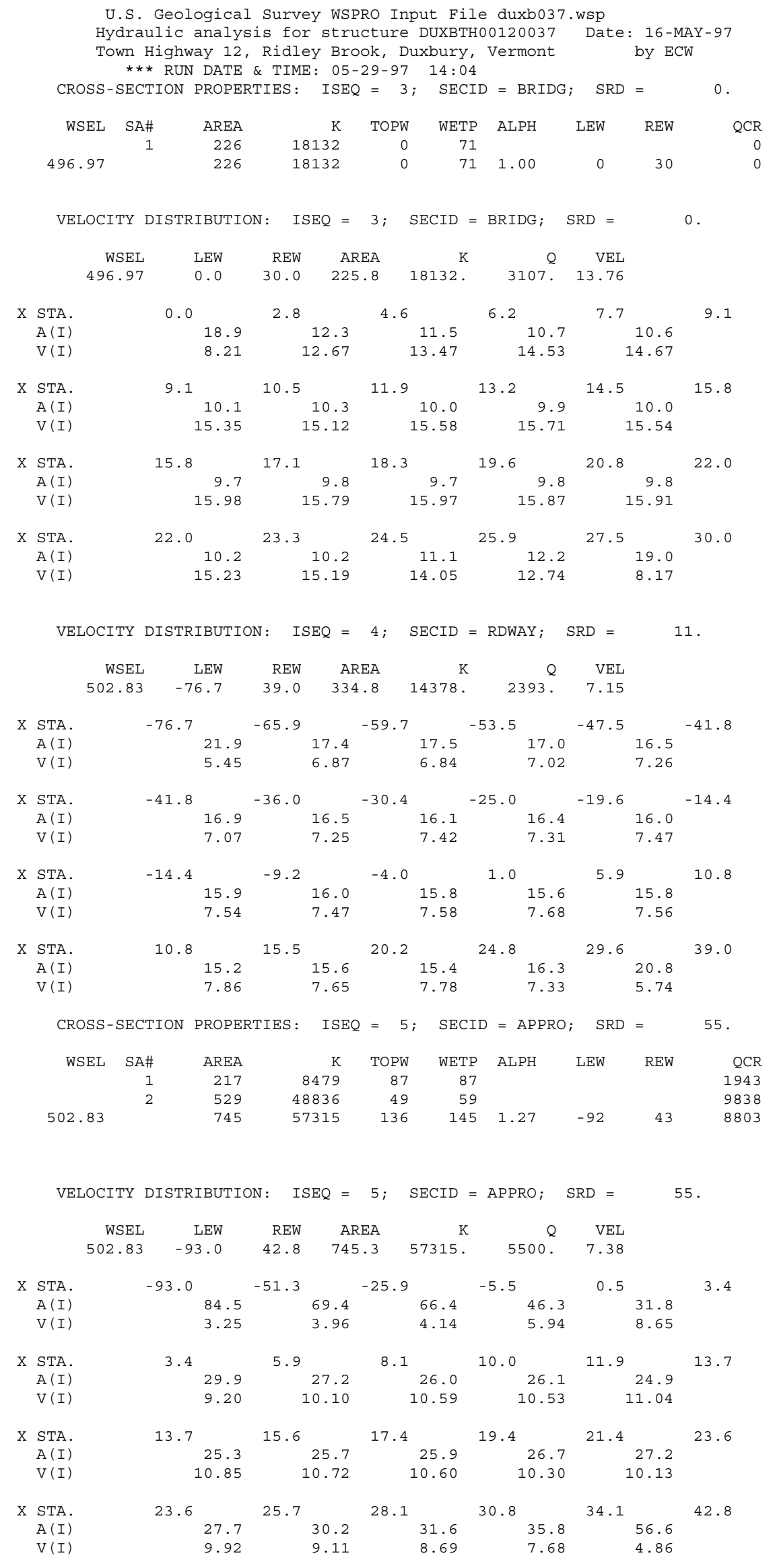


WSPRO OUTPUT FILE (continued)

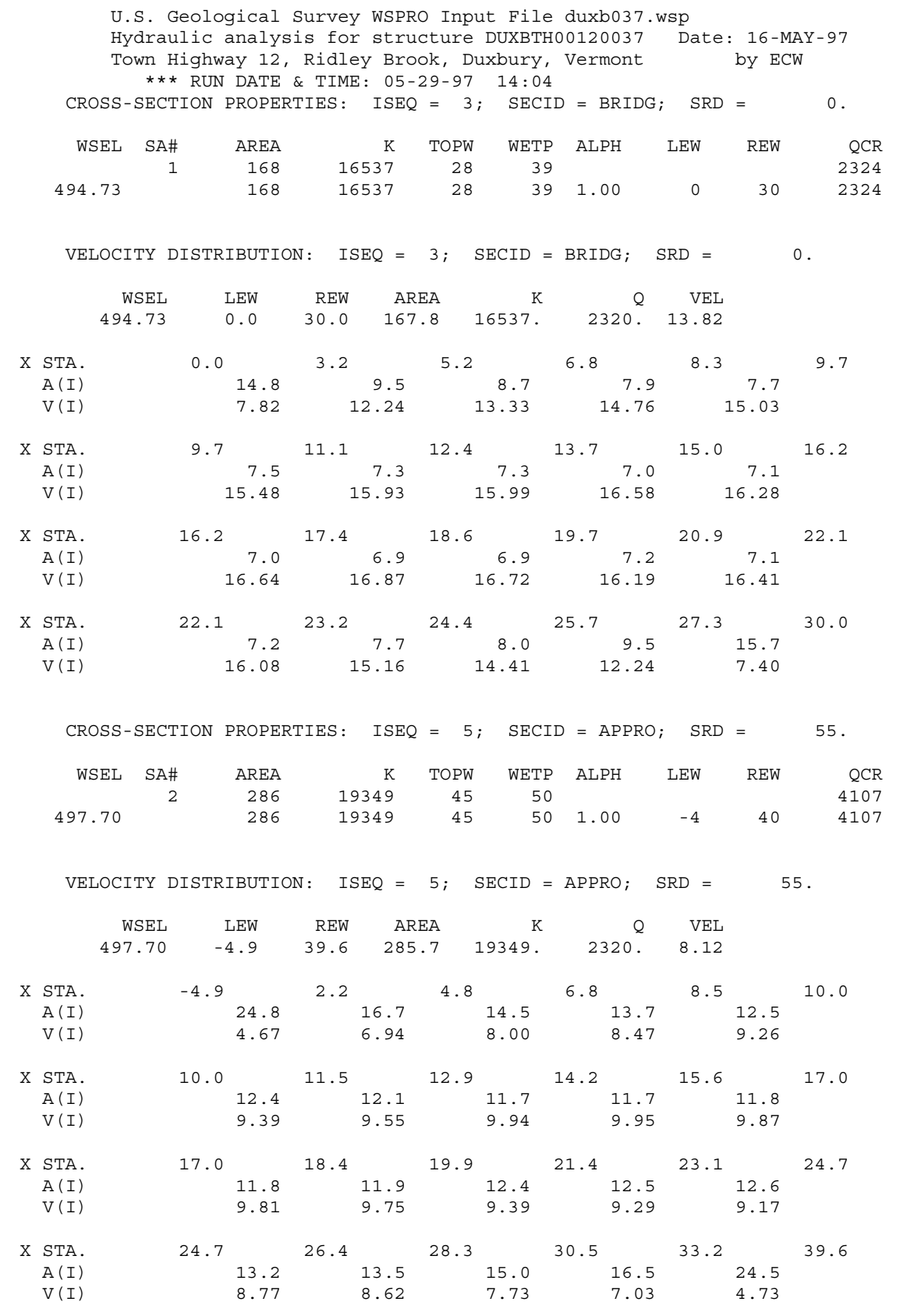


WSPRO OUTPUT FILE (continued)

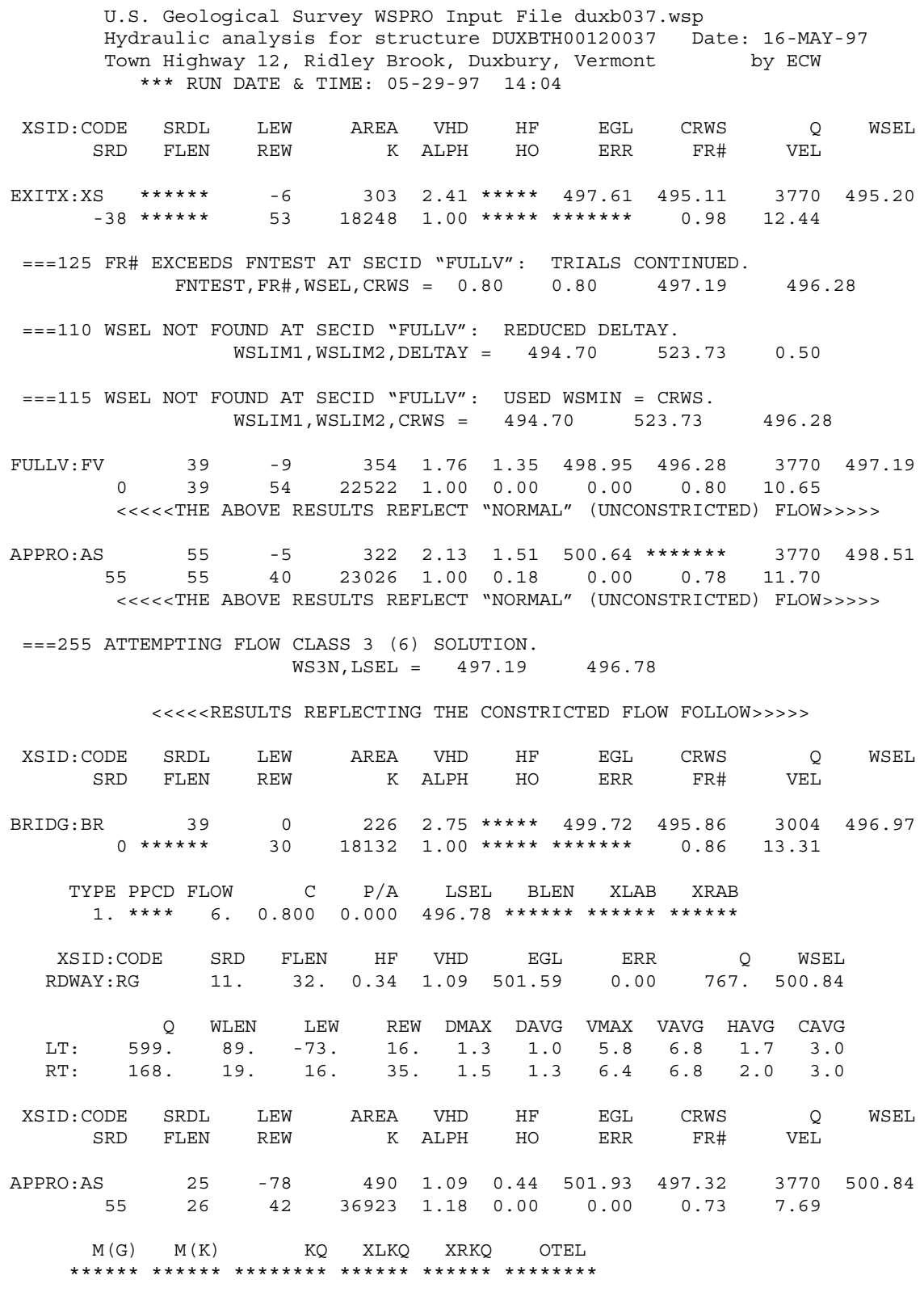

$<<<<<$ END OF BRIDGE COMPUTATIONS $>>>>>$

FIRST USER DEFINED TABLE.

\begin{tabular}{|c|c|c|c|c|c|c|c|c|}
\hline XSID : CODE & SRD & LEW & REW & $\mathrm{Q}$ & K & AREA & VEL & WSEL \\
\hline EXITX:XS & -39. & -7. & 53. & 3770 . & 18248. & 303. & 12.44 & 495.20 \\
\hline FULLV: FV & 0 . & -10 & 54. & 3770 . & 22522 . & 354. & 10.65 & 497.19 \\
\hline BRIDG : BR & 0 . & 0 . & 30. & 3004 . & 18132. & 226. & 13.31 & 496.97 \\
\hline RDWAY : RG & 11. & 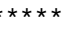 & 599. & 767. & $* \star \star \star \star \star \star \star * *$ & $\star \star \star \star \star *$ & 2.00 & 500.8 \\
\hline APPRO: AS & 55. & -79 & 42 . & 3770 . & 36923 . & 490 & 7.69 & 500.8 \\
\hline XSID : CODE & XLKQ & XRKQ & & & & & & \\
\hline
\end{tabular}

SECOND USER DEFINED TABLE.

$\begin{array}{lcrrrrrrrr}\text { XSID : CODE } & \text { CRWS } & \text { FR\# } & \text { YMIN } & \text { YMAX } & \text { HF } & \text { HO } & \text { VHD } & \text { EGL } & \text { WSEL } \\ \text { EXITX:XS } & 495.11 & 0.98 & 486.97 & 522.56 * * * * * * * * * * & 2.41 & 497.61 & 495.20 \\ \text { FULLV:FV } & 496.28 & 0.80 & 488.14 & 523.73 & 1.35 & 0.00 & 1.76 & 498.95 & 497.19 \\ \text { BRIDG : BR } & 495.86 & 0.86 & 487.97 & 496.97 * * * * * * * * * * & 2.75 & 499.72 & 496.97 \\ \text { RDWAY:RG } & * * * * * * * * * * * * * * * & 499.39 & 522.30 & 0.34 * * * * * * & 1.09 & 501.59 & 500.84 \\ \text { APPRO:AS } & 497.32 & 0.73 & 488.89 & 522.30 & 0.44 & 0.00 & 1.09 & 501.93 & 500.84\end{array}$


WSPRO OUTPUT FILE (continued)

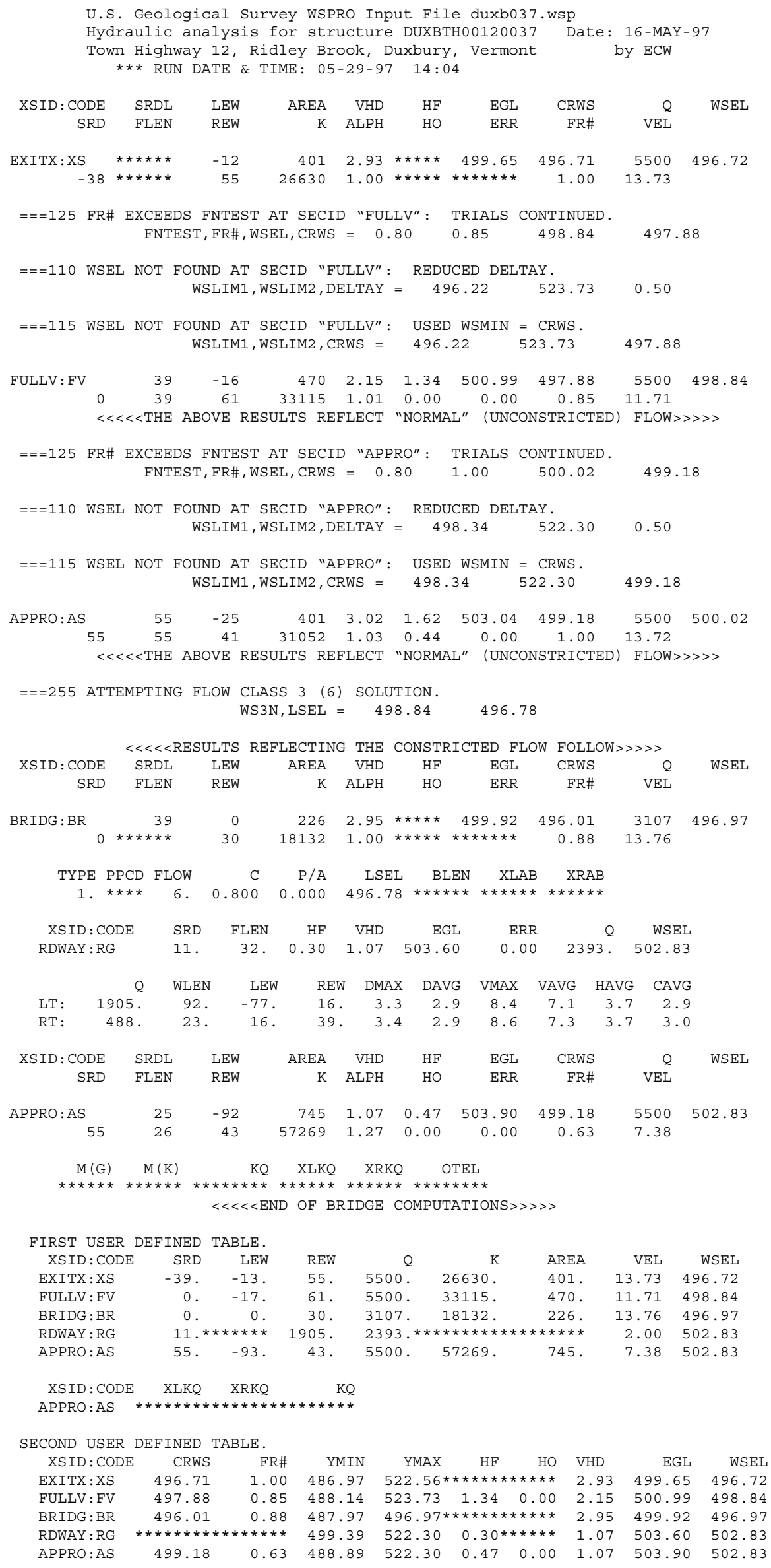


WSPRO OUTPUT FILE (continued)

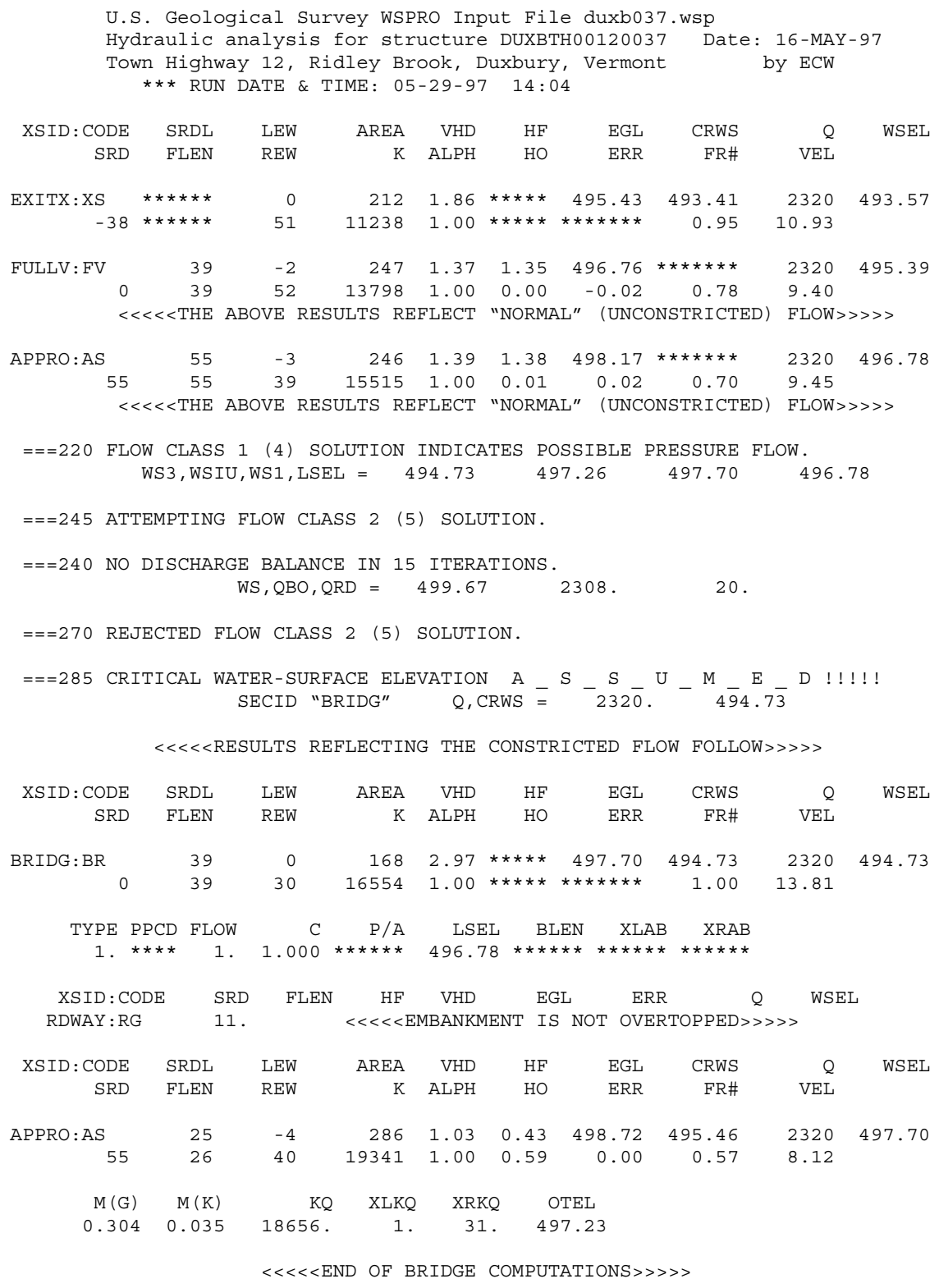

FIRST USER DEFINED TABLE.

\begin{tabular}{|c|c|c|c|c|c|c|c|c|}
\hline XSID : CODE & SRD & LEW & REW & $Q$ & $\mathrm{~K}$ & AREA & VEL & WSEL \\
\hline EXITX:XS & -39. & 0. & 51. & 2320 . & 11238 & 212 . & 10.93 & 493.57 \\
\hline FULLV:FV & 0 . & -3 & 52 . & 2320 . & 13798 & 247 . & 9.40 & 495.39 \\
\hline BRIDG : BR & 0 . & 0 & 30. & 2320 . & 16554 . & 168 & 13.81 & 494.73 \\
\hline RDWAY : RG & \multicolumn{3}{|c|}{$11 . * * \star * * * * * * * * \star * * *$} & 0 . & 0 . & 0. & \multicolumn{2}{|c|}{$2.00 * \star * \star * \star * * *$} \\
\hline APPRO : AS & 55. & -5 & 40. & 2320 . & 19341. & 286 & 8.12 & 497.70 \\
\hline XSID : CODE & XLKQ & XRKQ & & & & & & \\
\hline APPRO : AS & 1. & 31. & 1865 & & & & & \\
\hline
\end{tabular}

SECOND USER DEFINED TABLE.

$\begin{array}{lcrrrrrrrr}\text { XSID :CODE } & \text { CRWS } & \text { FR\# } & \text { YMIN } & \text { YMAX } & \text { HF } & \text { HO } & \text { VHD } & \text { EGL } & \text { WSEL } \\ \text { EXITX:XS } & 493.41 & 0.95 & 486.97 & 522.56 * * * * * * * * * * * * & 1.86 & 495.43 & 493.57 \\ \text { FULLV:FV } & * * * * * * * * & 0.78 & 488.14 & 523.73 & 1.35 & 0.00 & 1.37 & 496.76 & 495.39 \\ \text { BRIDG : BR } & 494.73 & 1.00 & 487.97 & 496.97 * * * * * * * * * * * & 2.97 & 497.70 & 494.73 \\ \text { RDWAY:RG } & * * * * * * * * * * * * * * & 499.39 & 522.30 * * * * * * * * * * * & 0.59 & 500.05 * * * * * * * \\ \text { APPRO:AS } & 495.46 & 0.57 & 488.89 & 522.30 & 0.43 & 0.59 & 1.03 & 498.72 & 497.70\end{array}$

ER

NORMAL END OF WSPRO EXECUTION. 


\section{APPENDIX C:}

\section{BED-MATERIAL PARTICLE-SIZE DISTRIBUTION}




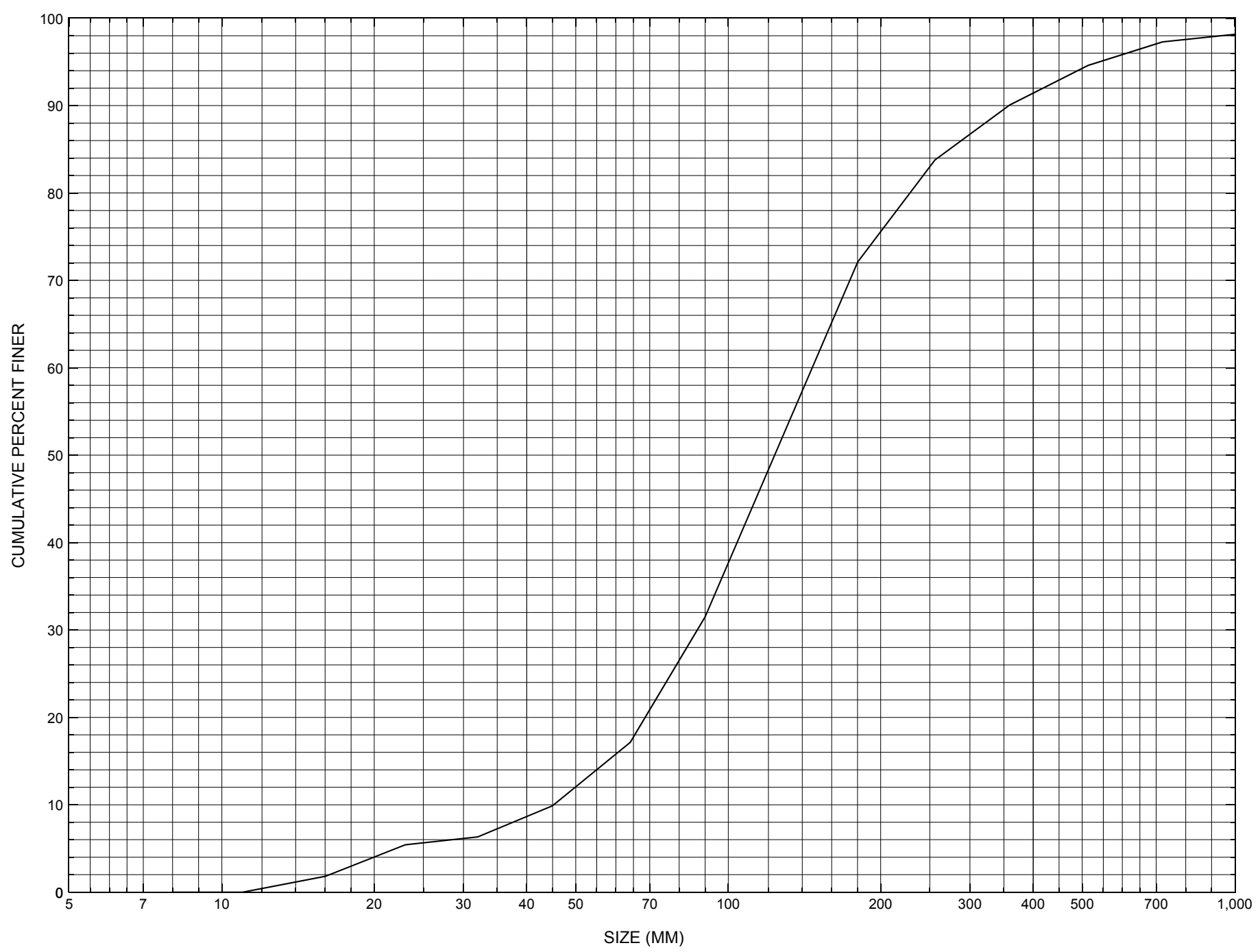

Appendix C. Bed material particle-size distribution for a pebble count in the channel approach of structure DUXBTH00120037, in Duxbury, Vermont. 


\section{APPENDIX D: \\ HISTORICAL DATA FORM}




\section{Structure Number DUXBTH00120037}

\section{General Location Descriptive}

Data collected by (First Initial, Full last name) $\underline{\mathbf{L}}$. Medalie

Date $(M M / D D / Y Y) \_10 / 13 / \underline{95}$

Highway District Number (I - 2; nn) $\mathbf{0 6}$

Town (FIPS place code; I - 4; nnnnn) $\mathbf{1 8 5 5 0}$

Waterway ( $($ - 6) RIDLEY BROOK

Route Number C3012

Topographic Map Waterbury

Latitude (I - 16; nnnn.n) $\mathbf{4 4 2 0 3}$
County (FIPS county code; I - 3; nnn)

Mile marker (I - 11; nnn.nnn) $\mathbf{0 0 0 0 0 0}$

Road Name (I - 7):

Vicinity (I - 9) 0.5 MI TO JCT W CL3 TH5

Hydrologic Unit Code: 2010003

Longitude (i - 17; nnnnn.n) $\mathbf{7 2 5 0 1}$

\section{Select Federal Inventory Codes}

FHWA Structure Number (I - 8) $\mathbf{1 0 1 2 0 6 0 0 3 7 1 2 0 6}$

Maintenance responsibility $(I-21 ; n n) \_\mathbf{0 3}$

Year built (I - 27; YYYY) 1967

Average daily traffic, ADT (I - 29; nnnnnn) 000200

Year of ADT (I - 30; YY) $\mathbf{9 2}$

Opening skew to Roadway $(I-34 ; n n) \quad 18$

Operational status $(I-41 ; X) \mathbf{A}$

Structure type (I - 43; nnn) $\mathbf{3 0 2}$

Approach span structure type $(I-44 ; n n n)$ 000

Number of spans (I - 45; nnn) $\underline{\mathbf{0 0 1}}$

Number of approach spans (I - 46; nnnn) $\mathbf{0 0 0 0}$

Comments:

According to the structural inspection report dated 5/23/94, the deck consists of 5 reinforced concrete precast panels. There is extensive rotting in the timber backwall of the RABUT. There is local scour along the RABUT footing. Both abutments have random fine cracking and have tipped towards the stream approx. 1 " at the top. The streambed is lined with cobbles and large boulders. There are gravel bars at the LABUT, and stonefill at the US wings. Streamflow is skewed towards the RABUT. There is heavy scaling and spalling at the RABUT footing and wings, with loss of a section at the bottom of the stem. There is some undermining at the RABUT between the stem and footing. (cont. on page 33) 


\section{Bridge Hydrologic Data}

Is there hydrologic data available? $\underline{\mathbf{N}}$ if No, type ctrl-n $h \quad$ VTAOT Drainage area $\left(\mathrm{mi}^{2}\right)^{2}$ :

Terrain character:

Stream character \& type:

Streambed material:

Discharge Data (cfs):

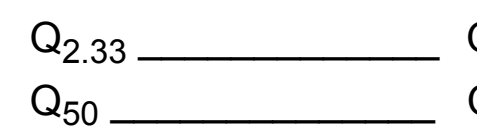

$Q_{10}$ $\mathrm{Q}_{100}$
$Q_{25}$

$Q_{500}$

Record flood date ( $M M / D D / Y Y$ ):

Estimated Discharge (cfs): Velocity at $Q$

Water surface elevation (ft):

Ice conditions (Heavy, Moderate, Light) : (ft/s):

Debris (Heavy, Moderate, Light):

The stage increases to maximum highwater elevation (Rapidly, Not rapidly):

The stream response is (Flashy, Not flashy):

Describe any significant site conditions upstream or downstream that may influence the stream's stage:

Watershed storage area (in percent): $\%$

The watershed storage area is: (1-mainly at the headwaters; 2- uniformly distributed; 3-immediatly upstream oi the site)

Water Surface Elevation Estimates for Existing Structure:

\begin{tabular}{|l|l|l|l|l|l|}
\hline $\begin{array}{l}\text { Peak discharge frequency } \\
\text { Water surface elevation (ft) } \\
\text { Velocity }(\mathrm{ft} / \mathrm{sec})\end{array}$ & $\mathrm{Q}_{2.33}$ & $\mathrm{Q}_{10}$ & $\mathrm{Q}_{25}$ & $\mathrm{Q}_{50}$ & $\mathrm{Q}_{100}$ \\
\hline
\end{tabular}

Long term stream bed changes:

Is the roadway overtopped below the $\mathrm{Q}_{100}$ ? (Yes, No, Unknown):

Frequency:

Relief Elevation (ft):

Discharge over roadway at $Q_{100}\left(f t^{3} / \mathrm{sec}\right)$ :

Are there other structures nearby? (Yes, No, Unknown): Upstream distance (miles): Town: If No or Unknown, type ctrl-n os

Highway No. : Structure No. : Year Built:

Clear span (ft): Clear Height (ft): Structure Type: Full Waterway $\left(t^{2}\right)$ : 
Downstream distance (miles): Town: Year Built:

Highway No. : Structure No. : Structure Type:

Clear span (ft): Clear Height (ft): Full Waterway $\left(f^{2}\right)$ :

Comments:

The LABUT US wing full-height vertical crack that is displaced approx. 0.5 " at its top. The RABUT has some settlement and has tipped.

\section{USGS Watershed Data}

Watershed Hydrographic Data Drainage area (DA) $\frac{\mathbf{1 0 . 1 5}}{\text { Witershed storage }^{2}}{ }^{\mathrm{0}}{ }^{\mathrm{0}}$ \%

Bridge site elevation $\mathbf{7 3 0} \mathrm{ft}$

Main channel length $\mathbf{4 . 7 2} \mathrm{mi}$

$10 \%$ channel length elevation $\mathbf{8 6 0}$

Lake/pond/swamp area $\underline{0}$ $\mathrm{mi}^{2}$

Headwater elevation $\quad \mathbf{3 6 8 8} \mathrm{ft}$

Main channel slope $(S) \quad \mathbf{4 7 4 . 5 7} \mathrm{ft} / \mathrm{mi}$

Watershed Precipitation Data

Average site precipitation in Average headwater precipitation in

Maximum 2yr-24hr precipitation event $(124,2)$ in

Average seasonal snowfall (Sn) $\mathrm{ft}$ 


\section{Bridge Plan Data}

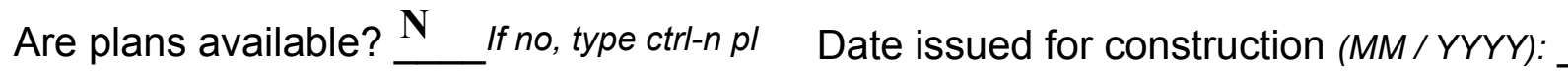
Project Number -

Minimum channel bed elevation:

Low superstructure elevation: USLAB DSLAB USRAB DSRAB Benchmark location description:

Reference Point (MSL, Arbitrary, Other): Datum (NAD27, NAD83, Other):

Foundation Type:

(1-Spreadfooting; 2-Pile; 3- Gravity; 4-Unknown)

If 1 : Footing Thickness Footing bottom elevation:

If 2: Pile Type: (1-Wood; 2-Steel or metal; 3-Concrete) Approximate pile driven length:

If 3: Footing bottom elevation:

Is boring information available? If no, type ctrl-n bi Number of borings taken:

Foundation Material Type: (1-regolith, 2-bedrock, 3-unknown)

Briefly describe material at foundation bottom elevation or around piles:

Comments: 


\section{Cross-sectional Data}

Is cross-sectional data available? $\underline{\mathbf{Y}}$

If no, type ctrl-n xs

Source (FEMA, VTAOT, Other)? VTAOT

This cross-section is of the upstream bridge face. The low cord elevations are from the 7/1/96

Comments: USGS survey log, in which the data was also collected at the upstream bridge face. The low cord to bed length data is from the sketch $(6 / 15 / 92)$ attached to the bridge inspection report $(5 / 23 / 94)$.

\begin{tabular}{|l|l|l|l|l|l|l|l|l|l|l|l|}
\hline Station & - & - & - & - & - & - & - & - & - & - \\
\hline Feature & - & - & - & - & - & - & - & - & - & - \\
\hline $\begin{array}{l}\text { Low cord } \\
\text { elevation }\end{array}$ & - & - & - & - & - & - & - & - & - & - & - \\
\hline $\begin{array}{l}\text { Bed } \\
\text { elevation }\end{array}$ & - & - & - & - & - & - & - & - & - & - & - \\
\hline $\begin{array}{l}\text { Low cord to } \\
\text { bed length }\end{array}$ & - & - & - & - & - & - & - & - & - & - & - \\
\hline \begin{tabular}{l} 
Station \\
\hline Feature
\end{tabular}$-$ & - & - & - & - & - & - & - & - & - & - \\
\hline $\begin{array}{l}\text { Low cord } \\
\text { elevation }\end{array}$ & - & - & - & - & - & - & - & - & - & - \\
\hline $\begin{array}{l}\text { Bed } \\
\text { elevation }\end{array}$ & - & - & - & - & - & - & - & - & - & - \\
\hline $\begin{array}{l}\text { Low cord to } \\
\text { bed length }\end{array}$ & - & - & - & - & - & - & - & - & - & - \\
\hline
\end{tabular}

Source (FEMA, VTAOT, Other)?

Comments: -

\begin{tabular}{|l|l|l|l|l|l|l|l|l|l|l|l|l|}
\hline Station & - & - & - & - & - & - & - & - & - & - \\
\hline Feature & - & - & - & - & - & - & - & - & - & - \\
\hline $\begin{array}{l}\text { Low cord } \\
\text { elevation }\end{array}$ & - & - & - & - & - & - & - & - & - & - & - \\
\hline $\begin{array}{l}\text { Bed } \\
\text { elevation }\end{array}$ & - & - & - & - & - & - & - & - & - & - \\
\hline $\begin{array}{l}\text { Low cord to } \\
\text { bed length }\end{array}$ & - & - & - & - & - & - & - & - & - & - & - \\
\hline \begin{tabular}{l} 
Station \\
\hline \begin{tabular}{l} 
Feature \\
\hline
\end{tabular}
\end{tabular}$-$ & - & - & - & - & - & - & - & - & - & - \\
\hline $\begin{array}{l}\text { Low cord } \\
\text { elevation }\end{array}$ & - & - & - & - & - & - & - & - & - & - \\
\hline $\begin{array}{l}\text { Bed } \\
\text { elevation }\end{array}$ & - & - & - & - & - & - & - & - & - & - \\
\hline $\begin{array}{l}\text { Low cord to } \\
\text { bed length }\end{array}$ & - & - & - & - & - & - & - & - & - & - \\
\hline
\end{tabular}




\section{APPENDIX E: \\ LEVEL I DATA FORM}


U. S. Geological Survey

Bridge Field Data Collection and Processing Form

Qa/Qc Check by: EW Date: $10 / 2 / 96$

\section{Structure Number DUXBTH00120037} Computerized by: $\underline{\mathbf{E W}}$ Date: $\underline{10 / 2 / 96}$

Reviewd by: $\quad$ EW Date: $\mathbf{5 / 2 8 / 9 7}$

\section{A. General Location Descriptive}

1. Data collected by (First Initial, Full last name) M. IVANOFF

2. Highway District Number 06

County WASHINGTON 023

Waterway (I - 6) RIDLEY BROOK

Route Number TH 12

3. Descriptive comments:

Located 0.5 miles to junction with Town Highway 5 .
Mile marker 000000

Town DUXBURY 18550

Road Name -

Hydrologic Unit Code: 2010003

Date $(M M / D D / Y Y) \underline{07} / \underline{01} / \underline{1996}$ 
18. Bridge Type: 1a

1a- Vertical abutments with wingwalls

1 b- Vertical abutments without wingwalls

2- Vertical abutments and wingwalls, sloping embankment

Wingwalls perpendicular to abut. face

3- Spill through abutments

4- Sloping embankment, vertical wingwalls and abutments

Wingwall angle less than $90^{\circ}$.

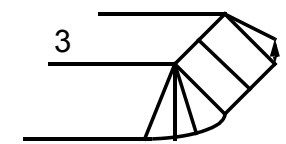

19. Bridge Deck Comments (surface cover variations, measured bridge and span lengths, bridge type variations, approach overflow width, etc.)

\#4: The left bank upstream surface cover is forest with Town Highway 12 adjacent to bank.

\#7: The values are from the Vermont AOT database. The measured span during the site visit was 30.5 feet.

\#13: The right bank downstream channel erosion consists of exposed stones behind the downstream right wingwall.

\#18: The ends of wingwalls are about 2 to 3 feet below low cord.

\section{Upstream Channel Assessment}

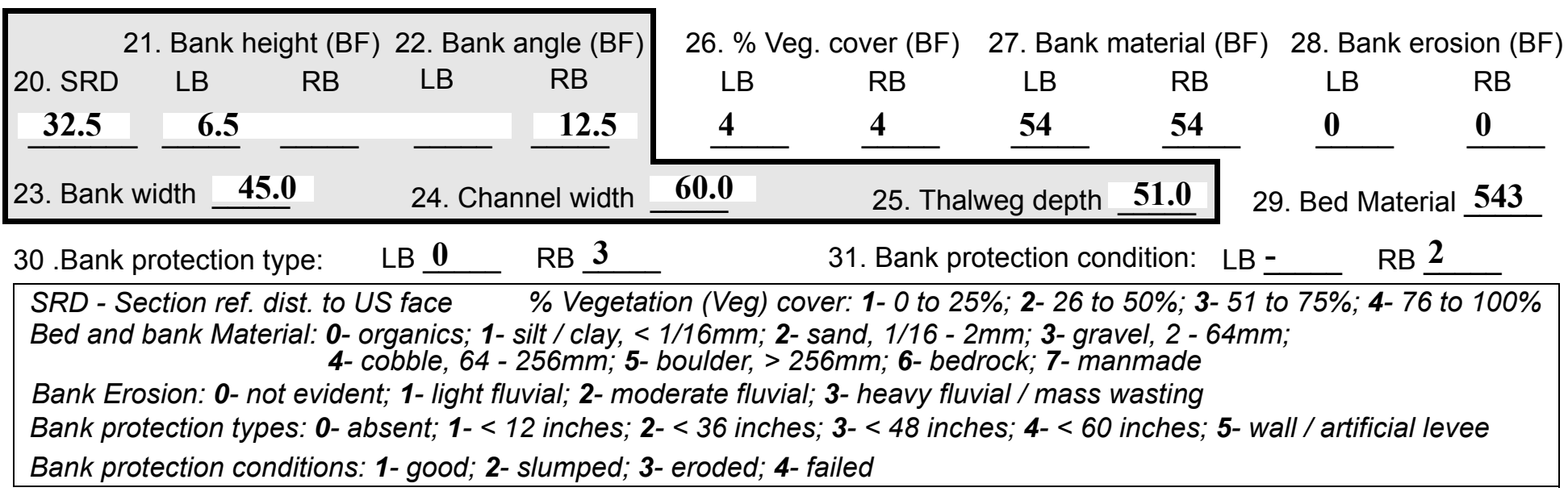

32. Comments (bank material variation, minor inflows, protection extent, etc.):

\#30: Right bank protection extends 25 feet upstream of bridge. 
36. Point bar extent: 215 feet $\underline{\mathbf{U S}}$ (US, UB) to $\underline{\mathbf{1 3 5}}$ feet $\underline{\mathbf{U S}}$ (US, UB, DS) positioned $\underline{\mathbf{0}} \%$ LB to $\underline{\mathbf{3 0}} \%$

37. Material: 34

38. Point or side bar comments (Circle Point or Side; Note additional bars, material variation, status, etc.):

39. Is a cut-bank present? $\mathbf{N}$ ( $Y$ or if $N$ type ctrl-n $c b)$

40. Where? - $(L B$ or $R B)$

41. Mid-bank distance: -

42. Cut bank extent: -

feet -

(US, UB) to feet (US, UB, DS)

43. Bank damage: -

(1- eroded and/or creep; 2- slip failure; 3- block failure)

44. Cut bank comments (eg. additional cut banks, protection condition, etc.):

NO CUT BANKS

45. Is channel scour present? $\mathbf{N}$ ( $Y$ or if $N$ type ctrl-n cs)

47. Scour dimensions: Length -

Width -

Depth : -

46. Mid-scour distance: -

48. Scour comments (eg. additional scour areas, local scouring process, etc.):

NO CHANNEL SCOUR

49. Are there major confluences? $\mathbf{N}$

51. Confluence 1: Distance -

Confluence 2: Distance -

52. Enters on -

Enters on -

54. Confluence comments (eg. confluence name):

NO MAJOR CONFLUENCES
50. How many? -

53. Type(1- perennial; 2- ephemeral)

Type (1-perennial; 2- ephemeral) ( $L B$ or $R B)$

\section{Under Bridge Channel Assessment}

55. Channel restraint (BF)? LB 2

56. Height (BF)
LB RB
$\mathbf{3 7 . 0}-$
58. Bank width (BF) -
(1- natural bank; 2- abutment; 3- artificial levee)

Bed and bank Material: 0- organics; 1- silt / clay, < 1/16mm; 2- sand, 1/16 - 2mm; 3- gravel, 2 - 64mm; 4- cobble, 64 - 256mm; 5- boulder, > 256mm; 6- bedrock; 7- manmade

Bank Erosion: 0- not evident; 1- light fluvial; 2- moderate fluvial; 3- heavy fluvial / mass wasting

64. Comments (bank material variation, minor inflows, protection extent, etc.):

5 
65. Debris and Ice Is there debris accumulation?

$(Y$ or $N)$ 66. Where? $\mathbf{N}$

(1- Upstream; 2- At bridge; 3- Both)

67. Debris Potential ( 1- Low; 2- Moderate; 3- High)

68. Capture Efficiency 2

(1-Low; 2- Moderate; 3- High)

69. Is there evidence of ice build-up? 2

Ice Blockage Potential $\underline{\mathbf{N}}$

(1- Low; 2- Moderate; 3- High)

70. Debris and Ice Comments:

1

Some trees leaning into the channel upstream and downstream with the bridge opening skewed to flow.

\begin{tabular}{|l|c|c|c|c|c|c|c|c|}
\hline Abutments & $\begin{array}{c}\text { 71. Attack } \\
\angle \text { (BF) }\end{array}$ & $\begin{array}{c}72 \text {. Slope } \angle \\
\text { (Qmax) }\end{array}$ & $\begin{array}{c}\text { 73. Toe } \\
\text { loc. (BF) }\end{array}$ & $\begin{array}{c}\text { 74. Scour } \\
\text { Condition }\end{array}$ & $\begin{array}{c}75 . \text { Scour } \\
\text { depth }\end{array}$ & $\begin{array}{c}\text { 76. Exposure } \\
\text { depth }\end{array}$ & 77. Material & 78. Length \\
\hline LABUT & & $\mathbf{0}$ & $\mathbf{9 0}$ & $\mathbf{2}$ & $\mathbf{2}$ & $\mathbf{0}$ & $\mathbf{0 . 1}$ & $\mathbf{9 0 . 0}$ \\
\hline RABUT & $\mathbf{1}$ & $\mathbf{2 0}$ & $\mathbf{9 0}$ & & & $\mathbf{2}$ & $\mathbf{2}$ & $\mathbf{2 8 . 0}$ \\
\hline
\end{tabular}

Pushed: $L B$ or RB

Toe Location (Loc.): 0- even, 1- set back, 2- protrudes

Scour cond.: 0- not evident; 1- evident (comment); 2- footing exposed; 3-undermined footing; 4- piling exposed; 5- settled; 6- failed

Materials: 1- Concrete; 2- Stone masonry or drywall; 3- steel or metal; 4- wood

79. Abutment comments (eg. undermined penetration, unusual scour processes, debris, etc.):

2.0

2.0

1

The left abutment footing is exposed at upstream end.

The right abutment footing is exposed with maximum scour at downstream end.

80. Wingwalls:

Exist? Material? Scour Scour Exposure $\begin{array}{ll}81 . & \\ \text { Angle? Length? }\end{array}$ Condition? depth? depth?

USLWW:

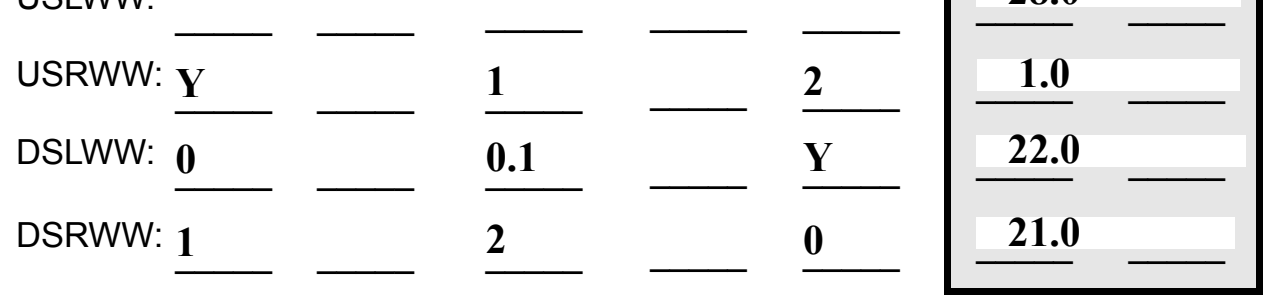

Wingwall materials: 1- Concrete; 2- Stone masonry or drywall; 3- steel or metal; 4- wood

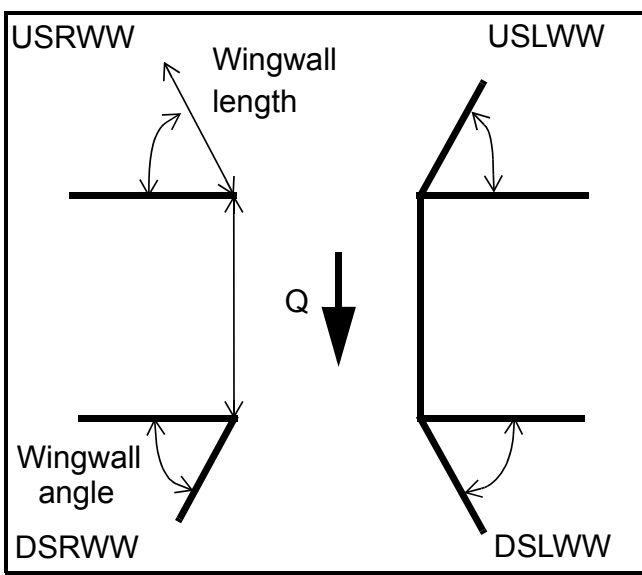

82. Bank / Bridge Protection:

\begin{tabular}{|l|l|l|l|l|l|l|c|c|}
\hline Location & USLWW & USRWW & LABUT & RABUT & LB & RB & DSLWW & DSRWW \\
\hline Type & $\mathbf{0 . 2}$ & $\mathbf{0}$ & $\mathbf{Y}$ & $\mathbf{2 . 0}$ & - & $\mathbf{2}$ & - & - \\
\hline Condition & $\mathbf{Y}$ & - & $\mathbf{1}$ & $\mathbf{2 . 0}$ & - & $\mathbf{1}$ & - & - \\
\hline Extent & $\mathbf{1}$ & - & $\mathbf{2}$ & $\mathbf{0}$ & $\mathbf{3}$ & $\mathbf{0}$ & $\mathbf{0}$ & - \\
\hline
\end{tabular}

Bank / Bridge protection types: 0- absent; 1- < 12 inches; 2- < 36 inches; 3- < 48 inches; 4- < 60 inches; 
83. Wingwall and protection comments (eg. undermined penetration, unusual scour processes, etc.):

-
-
-
-
-
0
-
-
0
-
-

\section{Piers:}

84. Are there piers? (Y or if $N$ type ctrl-n pr)

\begin{tabular}{|l|l|l|l|l|l|l|l|}
\hline \multirow{2}{*}{$\begin{array}{l}85 . \\
\text { Pier no. }\end{array}$} & \multicolumn{3}{|c|}{ width (w) feet } & \multicolumn{3}{c|}{ elevation (e) feet } \\
\cline { 2 - 8 } & w1 & w2 & w3 & e@w1 & e@w2 & e@w3 \\
\hline Pier 1 & & & & $\mathbf{2 5 . 0}$ & $\mathbf{1 1 . 5}$ & $\mathbf{8 5 . 0}$ \\
\hline Pier 2 & & & & $\mathbf{1 1 . 5}$ & $\mathbf{1 0 5 . 0}$ & $\mathbf{1 0 . 0}$ \\
\hline Pier 3 & & & - & $\mathbf{4 0 . 0}$ & $\mathbf{1 0 . 0}$ & - \\
\hline Pier 4 & - & - & - & - & - & - \\
-
\end{tabular}

\begin{tabular}{|l|l|l|l|l|}
\hline Level 1 Pier Descr. & 1 & \multicolumn{1}{|c|}{2} & 3 & \multicolumn{1}{|c|}{} \\
\hline 86. Location (BF) & & - & - & - \\
\hline 87. Type & & - & - & - \\
\hline 88. Material & & - & - & - \\
\hline 89. Shape & & - & - & - \\
\hline 90. Inclined? & & - & - & - \\
\hline 91. Attack $\angle$ (BF) & & - & - & - \\
\hline 92. Pushed & & - & - & - \\
\hline 93. Length (feet) & - & - & - & - \\
\hline 94. \# of piles & & - & - & - \\
\hline 95. Cross-members & & - & - & - \\
\hline 96. Scour Condition & & - & - & - \\
\hline 97. Scour depth & $\mathbf{N}$ & - & - & - \\
\hline 98. Exposure depth & - & - & - & - \\
\hline
\end{tabular}

LFP, LTB, LB, MCL, MCM, MCR, RB, RTB, RFP

1- Solid pier, 2- column, 3- bent

1-Wood; 2-concrete; 3- metal; 4- stone

1- Round; 2- Square; 3- Pointed

Y-yes; $N$ - no

$L B$ or $R B$

0- none; 1- laterals; 2- diagonals; 3- both

0- not evident; 1- evident (comment);

2- footing exposed; 3- piling exposed;

4- undermined footing; 5- settled; 6- failed 
99. Pier comments (eg. undermined penetration, protection and protection extent, unusual scour processes, etc.):

-
-
-
-
-
-
-
-
-
-

100.

\section{E. Downstream Channel Assessment}

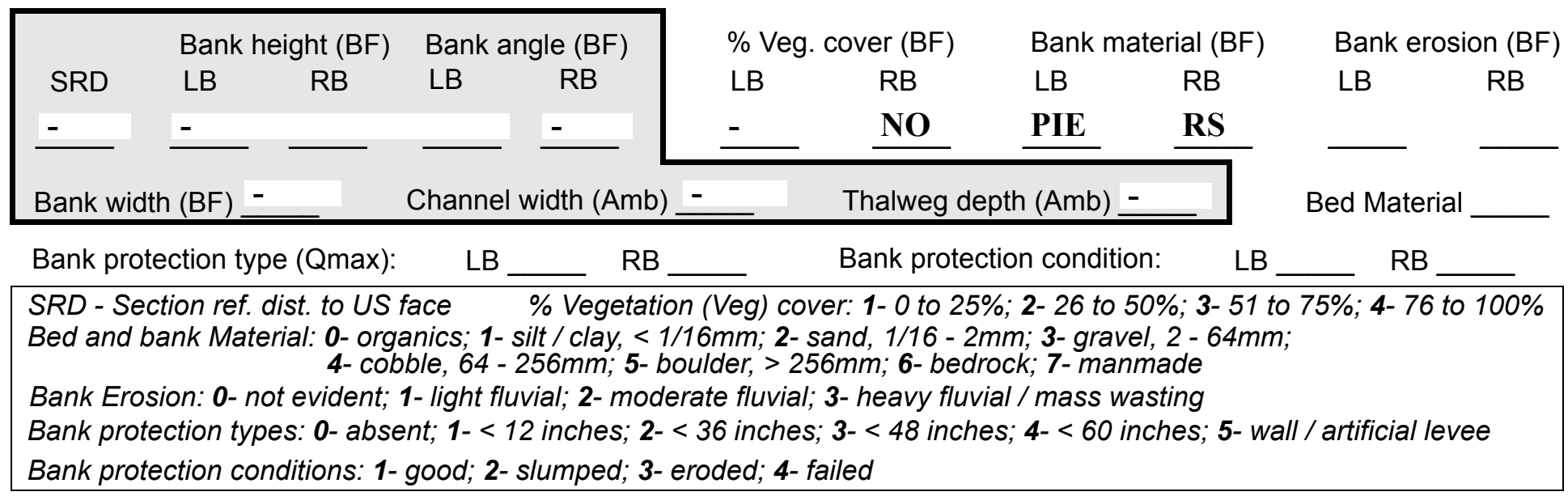

Comments (eg. bank material variation, minor inflows, protection extent, etc.):

4
4
546
54
1
1
543
0
0
-
-

101. Is a drop structure present? ( $Y$ or $N$, if $N$ type ctrl-n ds)

102. Distance: - feet

103. Drop: - feet 104. Structure material: (1- steel sheet pile; 2- wood pile; 3- concrete; 4- other)

105. Drop structure comments (eg. downstream scour depth): 
Point bar extent: feet

(US, UB, DS) to $\underline{\mathbf{N}}$ feet (US, UB, DS)

DS) positioned \%LB to DR \%RB

Material: $\mathbf{\text { OP }}$

Point or side bar comments (Circle Point or Side; note additional bars, material variation, status, etc.):

\section{STRUCTURE}

Is a cut-bank present? (Y or if $N$ type ctrl- $n$ cb) Where? (LB or $R B)$

Mid-bank distance: $\underline{\mathbf{Y}}$

Cut bank extent: $\underline{\mathbf{3 0}}$ feet $\underline{\mathbf{2 0}}$ (US, UB, DS) to $\underline{\mathbf{4 . 6}}$ feet $\underline{\mathbf{U B}}$ (US, UB, DS)

Bank damage: 55 (1-eroded and/or creep; 2- slip failure; 3- block failure)

Cut bank comments (eg. additional cut banks, protection condition, etc.):

DS

0

50

34

Is channel scour present? Sid (Y or if $N$ type ctrl-n cs) Mid-scour distance: $\underline{\text { e bar }}$ Scour dimensions: Length begi Width ns Depth: $\underline{\mathbf{4 . 6}} \quad$ Positioned feet $\%$ LB to fro $\%$ RB

Scour comments (eg. additional scour areas, local scouring process, etc.):

$m$ upstream bridge face.

An additional side bar extends along the right bank from 71 feet downstream to 180 feet downstream. The mid-bar distance is $\mathbf{1 2 0}$ feet downstream where it is 20 feet wide.

Are there major confluences? $\mathbf{Y}$ ( $Y$ or if $N$ type ctrl- $n$ mc)

Confluence 1: Distance 100

Enters on $\underline{40}$ (LB or RB)

How many? $\underline{\mathbf{L B}}$

Confluence 2: Distance 160

Enters on $\underline{\text { DS }}$ (LB or RB)

Type $\underline{\mathbf{D S}}$

(1- perennial; 2- ephemeral)

Confluence comments (eg. confluence name):

Type 1 (1-perennial; 2- ephemeral)

\section{F. Geomorphic Channel Assessment}

107. Stage of reach evolution

1- Constructed

2- Stable

3- Aggraded

4- Degraded

5- Laterally unstable

6- Vertically and laterally unstable 
108. Evolution comments (Channel evolution not considering bridge effects; See HEC-20, Figure 1 for geomorphic descriptors):

Y

$10 \mathrm{DS}$

25

15

2

75

100

N 


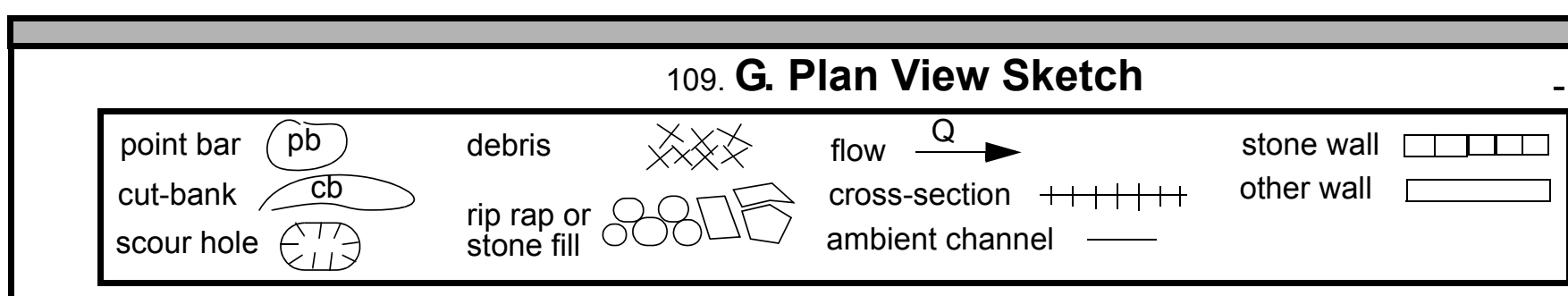


APPENDIX F:

SCOUR COMPUTATIONS 


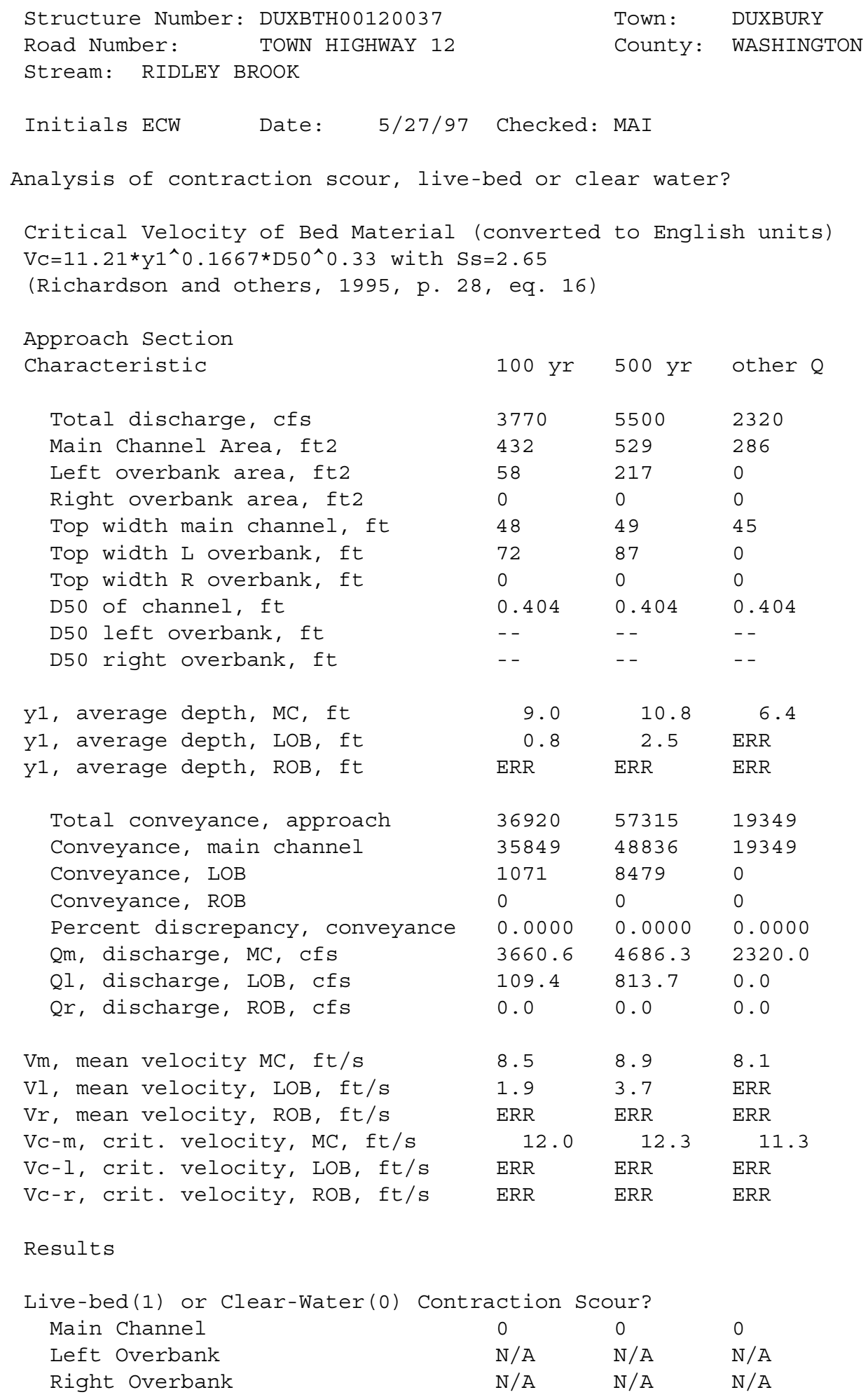


Clear water Contraction Scour in MAIN CHANNEL

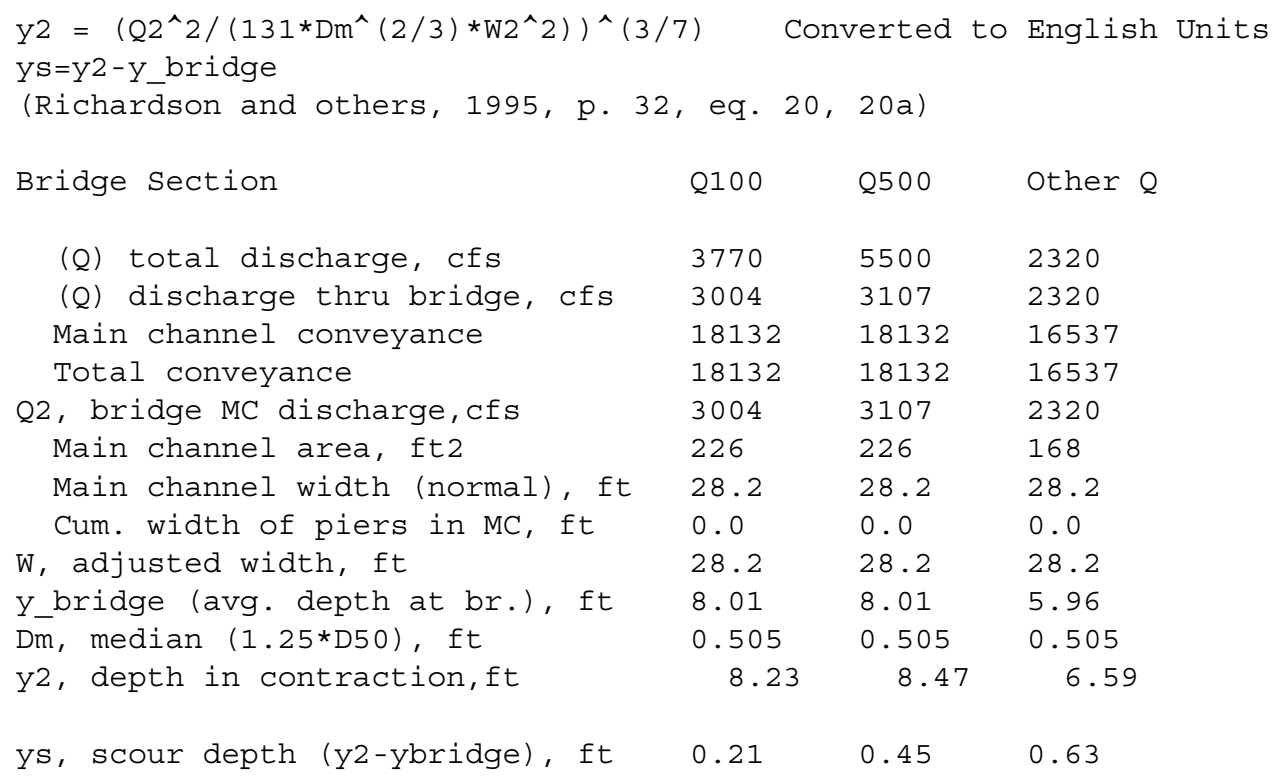




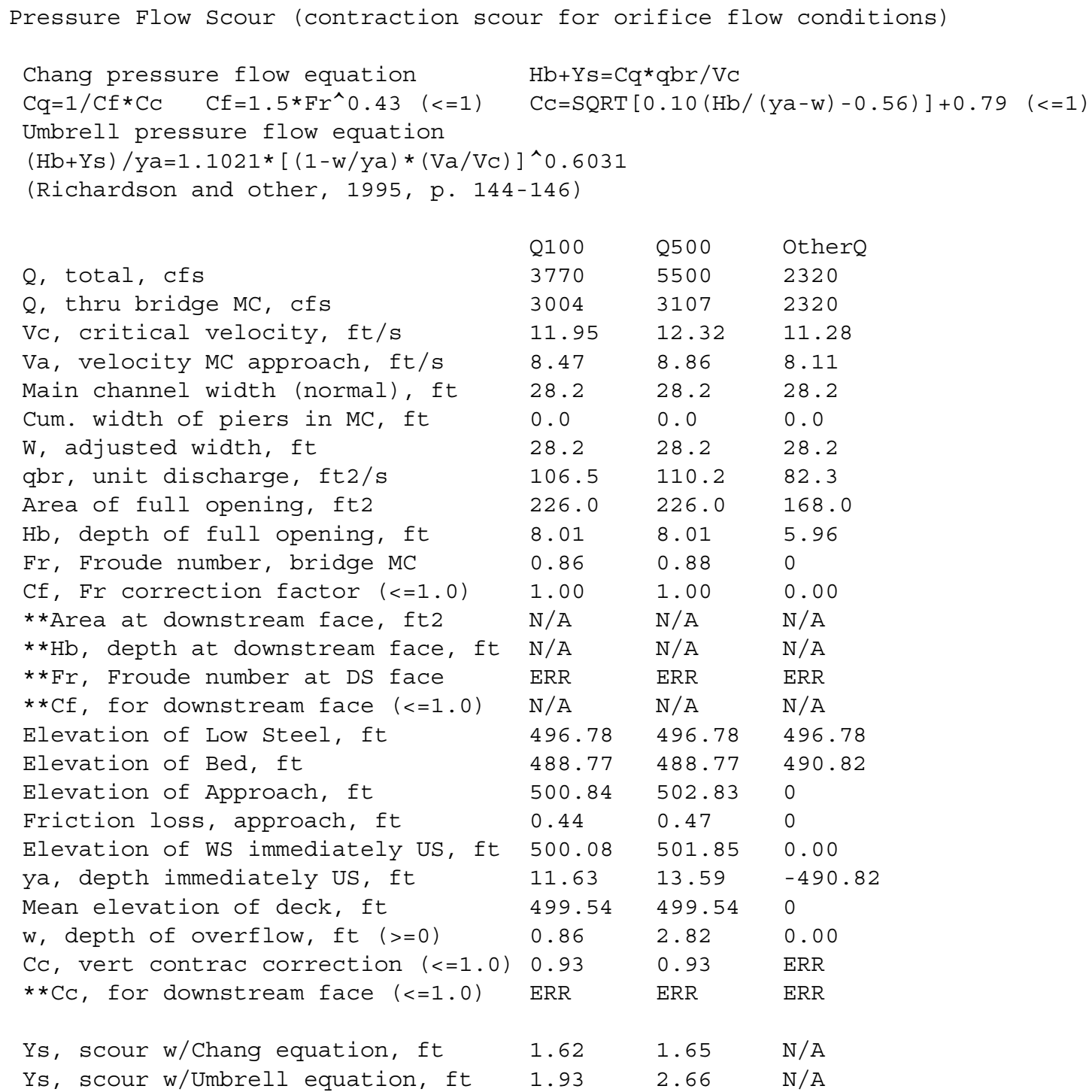




\begin{tabular}{|c|c|c|c|}
\hline \multicolumn{4}{|l|}{$\begin{array}{l}\text { Armoring } \\
\text { DC }=\left[\left(1.94 * \mathrm{~V}^{\wedge} 2\right) /(5.75 * \log (12.27 * \mathrm{y} / \mathrm{D} 90))\right. \\
\text { Depth to Armoring }=3 *(1 / \mathrm{PC}-1) \\
\text { (Federal Highway Administration, 1993) }\end{array}$} \\
\hline Downstream bridge face property & $100-y r$ & $500-y r$ & Other Q \\
\hline Q, discharge thru bridge $\mathrm{MC}$, cfs & 3004 & 3107 & 2320 \\
\hline Main channel area (DS), ft2 & 226 & 226 & 168 \\
\hline Main channel width (normal), ft & 28.2 & 28.2 & 28.2 \\
\hline Cum. width of piers, ft & 0.0 & 0.0 & 0.0 \\
\hline Adj. main channel width, ft & 28.2 & 28.2 & 28.2 \\
\hline D90, ft & 1.1754 & 1.1754 & 1.1754 \\
\hline D95, ft & 1.7679 & 1.7679 & 1.7679 \\
\hline Dc, critical grain size, ft & 0.9113 & 0.9748 & 1.1299 \\
\hline Pc, Decimal percent coarser than DC & 0.147 & 0.135 & 0.107 \\
\hline armoring, ft & 15.86 & 18.74 & 28.29 \\
\hline
\end{tabular}

Abutment scour

Froehlich's Abutment Scour

$\mathrm{Ys} / \mathrm{Y} 1=2.27 * \mathrm{~K} 1 * \mathrm{~K} 2 *\left(\mathrm{a}^{\prime} / \mathrm{Y} 1\right)^{\wedge} 0.43 * \mathrm{Fr} 1^{\wedge} 0.61+1$

(Richardson and others, 1995, p. 48, eq. 28)

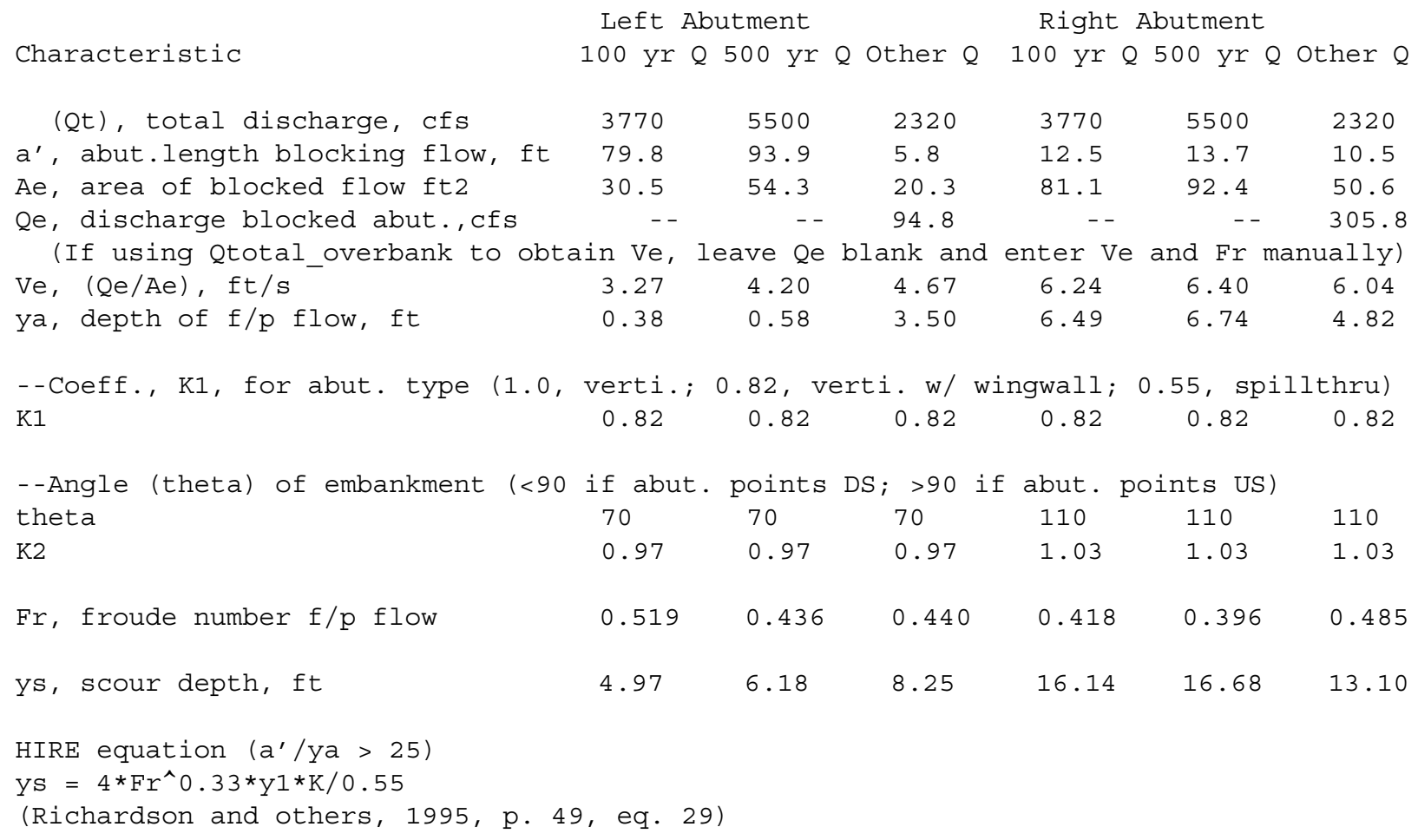




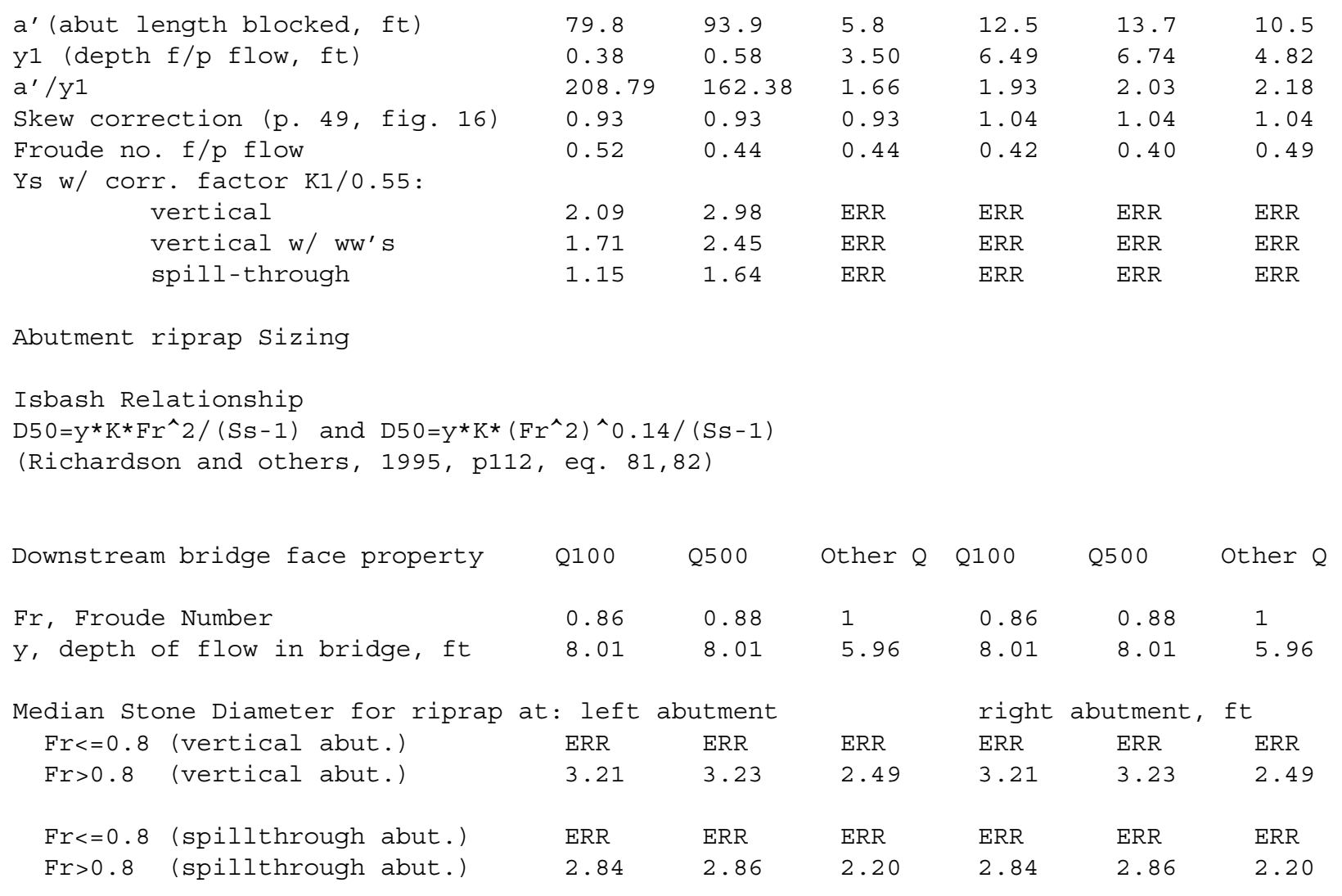


